A TALE OF TWO LABOR MARKETS:

INTERGENERATIONAL OCCUPATIONAL MOBILITY

IN BRITAIN AND THE U.S. SINCE 1850

\author{
Jason Long \\ Joseph Ferrie
}

Working Paper 11253 
NBER WORKING PAPER SERIES

\title{
A TALE OF TWO LABOR MARKETS: INTERGENERATIONAL OCCUPATIONAL MOBILITY \\ IN BRITAIN AND THE U.S. SINCE 1850
}

\author{
Jason Long \\ Joseph Ferrie \\ Working Paper 11253 \\ http://www.nber.org/papers/w11253
NATIONAL BUREAU OF ECONOMIC RESEARCH
1050 Massachusetts Avenue
Cambridge, MA 02138
March 2005

Extremely useful comments were provided on previous drafts by Robert $\mathrm{M}$ argo and Enrico Moretti and by participants at Northwestern University's Economic History Workshop and Institute for Policy Research Faculty Seminar, the Harvard Economic History Workshop, the 2002 meeting of the National Bureau of Economic Research Program in Cohort Studies, the 2002 Congress of the International Economic History Association, the 2003 Economic History Society Meetings, the 2004 ASSA Meetings, the 2004 European Social Science History Conference, and the 2004 All-UC Economic History Conference. The views expressed herein are those of the author(s) and do not necessarily reflect the views of the National Bureau of Economic Research.

(C2005 by Jason Long and Joseph Ferrie. All rights reserved. Short sections of text, not to exceed two paragraphs, may be quoted without explicit permission provided that full credit, including $\odot$ notice, is given to the source. 
A Tale of Two Labor Markets: Intergenerational Occupational Mobility in Britain and the U.S. Since 1850

Jason Long and Joseph Ferrie

NBER Working Paper No. 11253

March 2005

JEL No. J6, N3

\begin{abstract}
$\underline{\text { ABSTRACT }}$
The U.S. both tolerates more inequality than Europe and believes its economic mobility is greater than Europe's. These attitudes and beliefs help account for differences in the magnitude of redistribution through taxation and social welfare spending. In fact, the U.S. and Europe had roughly equal rates of inter-generational occupational mobility in the late twentieth century. We extend this comparison into the late nineteenth century using longitudinal data on 23,000 nationallyrepresentative British and U.S. fathers and sons. The U.S. was substantially more mobile then Britain through 1900, so in the experience of those who created the U.S. welfare state in the 1930s, the U.S. had indeed been "exceptional." The margin by which U.S. mobility exceeded British mobility was erased by the 1950s, as U.S. mobility fell compared to its nineteenth century levels.
\end{abstract}

\author{
Jason Long \\ Department of Economics \\ Colby College \\ jmlong@colby.edu \\ Joseph Ferrie \\ Department of Economics \\ Northwestern University \\ Evanston, IL 60208-2600 \\ and NBER \\ ferrie@northwestern.edu
}




\section{Introduction}

[W] have really everything in common with America nowadays, except, of course, language. Oscar Wilde, The Canterville Ghost (1887).

The economies of Britain and the U.S. have had much in common over the two centuries since the American Revolution: their legal traditions and property rights systems, sources of labor, capital, and technology, political ties and alliances in two world wars, and - Wilde's quip notwithstanding - language and culture are the most obvious. One significant respect in which they have differed, however, is the progressivity of their taxation and the scale of their social welfare spending, at least through the late 1970s. Policies in the U.S. reflect a belief that high rates of

economic mobility leave little need for substantial redistribution by the state. Public opinion surveys are consistent with these priorities and a belief in high rates of mobility: Americ ans are less concerned by inequality and are less willing to support redistribution than Europeans regardless of their position in the income distribution. (Alesina, Di Tella, and MacCulloch, 2001)

Since the 1970s, new large, nationally-representative longitudinal datasets for a variety of industrialized countries have made possible systematic cross-country mobility comparisons that call into question the assumptions regarding mobility that seem to underlie U.S. redistributive policies. The U.S. today exhibits no more income mobility or occupational mobility across generations than similarly developed countries (Solon, 2002; Solon, 1999; Erickson and Goldthorpe, 1992), though U.S. policies for the last 75 years have been predicated on American "exceptionalism" to the mobility patterns seen across a broad set of nations. Piketty (1995) provides a model of "dynastic learning" in which two economies can, as a result of differences in mobility in the past, settle upon 
and retain very different redistributive regimes even after their mobility patterns have converged. ${ }^{2}$

The question we address is whether we can identify, for Britain and the U.S., those historical differences in mobility, particularly intergenerational occupational mobility.

Commentators throughout the nineteenth century suggested that the U.S. was indeed "exceptional" in the occupational mobility experienced by its population (as well as in its geographic mobility). Using nationally-representative data for Britain and the U.S. that follows 23,000 pairs of fathers and sons from the beginning of the 1850 s to the beginning of the 1880 s, we offer the first detailed comparisons of the mobility regimes experienced by these two countries in the generation before they constructed their respective welfare states. In the process, we also offer a new perspective on the very different histories of labor relations and political activity by workers in Britain and the U.S. that past scholars (e.g. Turner in the 1890s; Sombart in the early 1900s; Thernstrom in the 1970s) have attributed to different amounts of economic opportunity and mobility by individual workers. Can we actually observe sufficiently la rge differences to explain these differences in labor radicalism?

Britain was chosen as the country to which to compare the U.S. experience because of the availability of comparable data (described below). But this is also a particularly illuminating comparison because of the large number of characteristics these two economies have shared since the middle of the nineteenth century when U.S. industrialization got underway. Intergenerational

\footnotetext{
${ }^{2}$ Piketty contends that "The multiplicity of steady states explains at the same time why different countries can remain in different redistributive equilibria, although the underlying structural parameters of mobility are essentially the same. This is particularly likely if a country exhibited for some time in the past a significantly different experie nce of social mobility before jo ining the 'comm on' pattern. The 'canonical' application is the United States, whose nineteenth century mobility and class struc ture diffe red signific antly from that of Euro pe before the two countrie s [sic] converged in the twe ntieth century." (p. 554) As we shall see below, the extent of the difference in mobility between the nineteenth century U.S. and the twentieth century U.S. is itself a subject of some controversy and one upon which we offer new evidence below.
} 
occupational change was adopted as the metric for mobility for reasons of convenience as well: it is the only economic outcome that can be examined throughout the period since 1850. It is in some ways superior to income as a measure of mobility, and in some ways inferior. ${ }^{3}$ But it is what we have, and has already been the object of a great deal of research in sociology where methods to analyze mobility have evolved substantially since the 1960 s.

\section{Previous Research on $19^{\text {th }}$ Century Mobility in Britain and the U.S.}

Our primary interest is in (1) assessing the differences in mobility between Britain and the U.S. in the second half of the nineteenth century; (2) comparing that difference to the difference observed by the 1970s; and (3) explicitly evaluating the change in mobility within the U.S. from the second half of the nineteenth century to the second half of the twentieth. ${ }^{4}$ There has been until now a lack of appropriate data to undertake any of these tasks (though there has been considerable work comparing twentieth century mobility rates across a set of developed countries, including Britain and the U.S., in the absence of data adequate to task (1), it has not been possible to say how mobility differences among countries have changed over long periods of time). We briefly survey the existing literatures in these areas before proceeding to our own contribution.

The comparison between Britain and the U.S. in the nineteenth century has been marked by the boldest pronouncements and the weakest empirical evidence. Britain has been viewed, since the time of de Tocqueville and Marx, as a considerably more rigid system in which family background plays a much more significant role is determining current prospects than in the U.S. These

\footnotetext{
${ }^{3}$ Björklund and Jäntti (1999, pp. 15-19) summarize some of the relative merits of income and occupation for the measurement of intergenerational mobility, and discuss scenarios in which they provide very different results. McMurrer et al. (1997) offer a similar discussion of the relative advantages of different measu res of interg enerational mobility.

${ }^{4}$ No explicit comparison for B ritain between mobility in the sec ond half of the nineteenth cen tury and in the second half of the twentieth century is made because of data comparability issues discussed below.
} 
differences have been attributed to a number of factors - the frontier and the rapid growth of completely new cities in the U.S., the feudal tradition and guild and apprenticeship systems in Britain, and the wide availability of free, public education in the U.S. ${ }^{5}$ But there has been no consistent data with which these assertions could be directly tested. There are several studies that have looked at both British nineteenth century mobility and U.S. nineteenth century mobility in isolation.

For nineteenth century Britain, Miles (1993 and 1999) and Mitch (1993) have each used samples of marriage registrations from 1839 to 1914 to measure intergenerational occupational

\footnotetext{
${ }^{5}$ In the 1830s, de Tocque ville noted, "Am ong aristo cratic peo ples, families remain for cent uries in the same condition and often in the same place.... Among democratic peoples [e.g. in the U.S.], new families continu ally spring from nowhere while others disap pear to no where and all the rest change their complexion." Three decades later in the 1860 s, Marx saw the U.S. as more open and fluid than the older European societies, with their "developed formation of classes." American classes, on the other hand, "have not yet become fixed but continually change and interchange their elements in constant flux." He related "this situation to the immature character of the American working-class movement." He characterized the U.S. as having "a continuous conversion of wage laborers into independent self-sustaining peasants. The position of wages laborer is for a very large part of the American people but a probational state, which they are sure to leave within a longer or a shorter te rm." A few years after the U.S. Cens us Bureau de clared that the country's internal frontier no longer existed, Frederick Jackson Turner (1921, Chapter IX) described social mobility, particula rly that in the western state, as crucial in the develo pmen t of Am erican de mocracy: "Th is, at least, is clear: Am erican de mocracy is fund amentally the outcome of the ex periences of the American people in dealing with the West. Western democracy through the whole of its earlier period tended to the production of a society of which the most distinctive fact was the freedom of the individual to rise under conditions of social mobility, and whose ambition was the liberty and well-being of the masses." In the first decades of the early twentieth century, Werner Sombart (1906) attributed the absence of socialism in the U.S. to higher rates of occupational mobility than in Europe. In the 1970s, Thernstrom shared Marx's and Sombart's belief that nineteenth century American workers enjoyed greater opportunity for social mobility than did their European counterparts, and that this heightened class fluidity had much to do with America's particular environment of class relations and labor organization:
}

Ame rican wo rkers... failed to flock into la bor and socialist parties to the same ex tent as their European counterparts in the late nineteenth and twentieth centuries because of the greater permeability of the class structure that governed their lives... The American class system... allowed substantial privilege for the privileged and extensive opportunity for the underprivileged to coexist simultaneously. It is tempting to argue that...[this] explains...the relative absence of acute class conflict in our political history.

Thernstrom goes on to point out that "as yet, there have not been enough quantitative studies of mobility in the European past to make systematic comparison possible." (Thernstrom, 1973). 
mobility. ${ }^{6}$ At the time of registration, both bride and groom as well as bride's father and groom's father were required to list their occupation. From this information, Miles calculates that between 60 and 68 percent of grooms married between 1839 and 1894 were in the same occupational class as their fathers when the grooms married. (Miles, 1999, p. 29). Though his finding are in general quite similar, Mitch finds evidence for slightly more mobility -61 percent of grooms married between 1869 and 1873 were in the same class as their father, 20 percent were higher, and 19 percent lower. The data used in both studies, however, are less than ideal. ${ }^{7}$

For the nineteenth century U.S., a large number of studies have been completed for specific communities in the U.S. that give us a rough sense of occupational mobility in the past. For example, among males who remained in Boston, from 37 to 40 percent of sons ended up in the same occupational categories as their fathers over the period 1840-89. (Thernstrom, 1973, p. 83) Though this might in itself seem a sufficient basis on which to conclude that the nineteenth century U.S. had greater intergenerational occupational mobility than nineteenth century Britain (total mobility - the fraction of sons found outside their fathers' occupational categories - was twice as great in Boston as in Britain), the data for Boston suffers, like that from Britain, from a number of shortcomings that prevent such simple comparisons. ${ }^{8}$

\footnotetext{
${ }^{6}$ Their samples were somewhat different. They both used marriage registries, but they used different (possibly overlapping) samples of registries.

${ }^{7}$ The marriage registry data include only couples married in Anglican churches, so toward the end of the nineteenth century, these samples are increasingly unrepresentative. By 1914, 42 percent of all marriages took place outside the Anglican church (Vincent, 1989, p. 281). Also, the occupations of the groom and his father are recorded at the time of the groom's marriage, so the father's and son's occupations are observed at different points in their life cycles, with the son being conside rably you nger than the father. If it were possible to observe the father's and son's occupations holding age constant, a different picture of intergenerational mobility might emerge. Specifically, we might expect to observe a greater likelihood of mobility as the son gained years and experience in the labor market.

${ }^{8}$ The principal difficulty with historical estimates for the U.S. is that they were most often constructed by observing a single com munity over a period of decad es. The only individuals whose
} 
Two additional difficulties apart from the inconsistencies in the collection of the data and biases introduced by the source materials are: (1) the possibility that differences between the British and U.S. occupational structures account for much of the difference in total mobility; and (2) the possibility that even in the absence of these differences in occupational distributions, the imprecision of the mobility measure employed would obscure more fundamental differences or similarities in mobility. The measu res of mobility provided in our analysis overcome these difficulties.

One study offers a long-run perspective on intergenerational occupational mobility within Britain: Miles (1999) attempts to reconcile his findings of increasing fluidity over the nineteenth and early twentieth centuries with work by Erickson and Goldthorpe (1992), among others, who discern no trend in intergenerational mobility from the 1940s to the 1970s. Differences in the data for the two eras (Miles used marriage registers and Erickson and Goldthorpe relied on survey data with a retrospective question on the occupation of the respondent's father when the respondent was 14 years of age) diminish the reliability of this comparison.

Only two studies have attempted to assess how intergenerational mobility changed between the nineteenth and twentieth centuries in the U.S. In a re-analysis of several city-specific studies from the nineteenth century and together with the Occupational Change in a Generation (OCG) cohorts for the twentieth, Grusky (1987) concluded that there was significant immobility in the

occupational mobility could be observed were those who remained in the community. It would be surprising if the movers and stayers did not have systematically different patterns of occupational mobility, given the positive and often substantial costs of migration. Occupational mobility measured using marriage records suffers from the same shortco ming as the British data: sons' occupations a re examined at different points in their careers than fathers' occupations. The new nineteenth century data used below for the U.S. (like that for Britain) is not limited to individuals who remained in a place for a decade or more and examines sons' and fathers' oc cupations at similar ages, presenting a more rep resentative picture of mobility than has previously been available. Though Thernstrom asserted his findings for Boston were consistent with an "American Pattern," othe rs were less sangu ine regarding m obility in the nineteenth century. Summ arizing the literature on intergenerational mobility in the past, McMurrer et al. (1997) conclude, "Overall, the existing evidence sugges ts that mobility was likely not as great as sugge sted by popular lite rature and the w ritings of Tocque ville on the openness of American socie ty. Most of the rich during earlier periods w ere ap parently born rich." 
nineteenth century, with the non-manual/manual divide particularly difficult to cross, and an

increase in intergenerational mobility from the nineteenth century to the twentieth century.

The work by Guest et al. (1989) is closest to the comparison between U.S. mobility in the nineteenth century and twentieth centuries carried out below. Comparing a sample of young males linked from the 1880 U.S. census to the 1900 U.S. census, they find little change from the last two decades of the nineteenth century to the end of the period covered by the second OCG cohort (1973). Their comparison is less than entirely apt, however. Their nineteenth century data excluded most interstate migrants, and the time between the observation of the fathers' and sons' occupations was in all cases greater (by as much as a factor of two) in the nineteenth century data than in the twentieth century data. ${ }^{10}$

\footnotetext{
${ }^{9}$ Grusky concludes, “This case for 'American Exceptionalism' can be evaluated only by comparing the data for Europe and America in the nineteenth century. It should be clear, however, that the present study casts doubt on this interpretation [that current belief in high rates of mobility in the U.S. results from rates that were indeed higher than those elsewhere in the past, though the U.S. rate some time ago converged to the more general pattern], since the rates of mobility in the U nited States have increased over the last cent ury." (Grusky, 1987, p. 120) Though Grusky's data make it possible for him to compare mobility over more than a century, there are significant parts of the population excluded from the nineteenth century samples he employs because they are based on the population that remained resident for a decade or more in a set of four cities and towns (Pough keepsie, NY; Holland, MI; Atlanta, GA; and Boston, MA). These samples necessa rily exclude (1) anyone who migrated into or out of any of these cities during the time period examined; (2) farmers and farm laborers living outside these cities and towns (at time when half of the civilian labor force was employed in agriculture and most of them lived outside cities and towns); and (3) any rural residents (at a time when more than three quarters of the U.S. population still lived in places of fewer than 2,500 inhabitants).

${ }^{10}$ In their nineteenth century data, the individual's father's occupation was observed in 1880 , and the individual's own occupation was observed in 1900, twenty years later. In the two OCG cohorts, the individual's own occupation was observed in the survey year (1962 or 1973), but the father's occupation reported was that for the father when the respondent was 16 years of age. Guest et al. (1989) used males from the OCG who were 25-34 in the survey year, so they have between 9 (for 25 year olds) and 18 years (for 34 year olds) betwe en the rep ort of their father's occupation and the report of their own.
} 
The literature comparing twentieth century intergenerational mobility across developed countries is now voluminous. ${ }^{11}$ The comparison between Britain and the U.S. undertaken by Kerckhoff et al. (1985), like almost all international comparisons involving these two countries, uses the Oxford Social Mobility Study (1972) for Britain and the second cohort of the OCG (1973) for the U.S. They find "considerably more overall inter-generational and career mobility in the United States, but ... the major differences between the two societies are due to shifts in the distributions of kinds of occupations.” (1985, p. 281). Erickson and Goldthorpe (1992) examine a broader set of countries, and likewise find the U.S. and Britain roughly similar in intergenerational mobility, after accounting for differences in the distributions of occupations across the two countries, as did Grusky and Hauser (1984) in analyzing a set of 16 countries including Britain and the U.S. ${ }^{12}$ In income terms, Solon (2002) and Björklund and Jäntti (1999) find similarly high rates of income immobility across generations in Britain and the U.S., with both exhibiting considerably less mobility from fathers to sons than Canada, Finland, and Sweden.

\section{The Data}

We use a common methodology in constructing nineteenth century data to compare mobility between the U.S. and Britain. For both countries we link a sample of males from the $1850 / 1851$ census to the census taken thirty years later in 1880/1881. Our choice of Britain as a comparison was dictated by the availability of sources making it possible to construct longitudinal data in exactly the same manner as for the U.S. For Britain we use information on approximately 13,000 males linked from the 1851 British census to the 1881 British census, and for the U.S. on

\footnotetext{
11 Treiman and Ganzenboom (2000) provide a useful survey of the entire history of comparative research on occupational mobility, both within and across generations.

12 Contrasting view s are found in W ong (1990) who finds greater mobility in Britain than in the U.S., and Yamaguchi (1987) who finds mobility greater in the U.S. than in Britain.
} 
nearly 10,000 males linked from the 1850 to the 1880 U.S. Federal Censuses. Details on the matching procedure, representativeness, and sensitivity tests are described in the Appendix.

The only economic outcome available in the longitudinal data used here is self-reported occupation. We observe the father's occupation in 1850 (U.S.) or 1851 (Britain) and the son's occupation thirty years later. After collapsing hundreds of occupational titles into a reasonable set of categories it becomes possible to construct tables that describe the transitions from fathers' occupational categories to sons' occupational categories. We have used four categories (white collar, farmer, skilled and semi-skilled, and unskilled) to reduce the sparseness of the mobility tables, but where it has been possible to use a larger number of categories, the basic qualitative results reported below are unchanged. ${ }^{13}$

For the twentieth century, we have employed the same data as others who have worked in this area: the Oxford Mobility Study for Britain and the OCG (1973 cohort) for the U.S. ${ }^{14}$ In each the respondent's occupation at the time of the survey is taken as the son's occupation, and the occupation that the respondent reported his father to have had when the respondent was age 14 (Britain) or 16 (U.S.) is taken as the father's. To prevent differences in the impact of the Great Depression from influencing the results, males age 31-37 (whose fathers' reported occupations would have been in 1949-1955) were u sed from the British data and males age 33-39 (whose fathers' reported occupations would have been in 1950-1956) were used from the U.S. data. This yields a

\footnotetext{
13 "White Collar" is comprised of professional, technical, and kindred; managers, officials, and proprietors; clerical; and sales. "Farmer" is comprised of only farm owners and farm managers. "Skilled/S emiskilled" is comprised of craftsmen and operatives. "U nskilled" is comprised of service workers and laborers, including farm laborers.

${ }^{14}$ The Oxford Mobility Study for Britain is available at the U.K. Data Archive at the University of Essex as study number 1097. See http://www.dataarchive.ac.uk/. The Occupational Change in a Generation study is available from the Inter-University Consortium for Political and Social Research as study number 6162. See http://www.icpsr.umich.edu/.
} 
range of years between fathers' and sons' occupations of 17 to 23 years, and an average of roughly 20. This was done to ensure comparability with the U.S. data from the nineteenth century: though the direct nineteenth century comparison between Britain and the U.S. will use a thirty-year interval between fathers' and sons' occupations (a restriction dictated by the sources available for Britain), the U.S. sources also allowed the creation of two twenty-year samples (one with fathers observed in 1860 and sons observed in 1880, and one with fathers observed in 1880 and sons observed in 1900). These will be used for assessing change in mobility over time within the U.S. ${ }^{15}$

\section{Measu ring and Modeling Intergenerational Occupational Mobility}

Intergenerational occupational mobility can be assessed through the analysis of simple two dimensional matrices, with categories for fathers' occupations arrayed across one dimension and categories for sons' occupations arrayed across the other. Comparing mobility across two places or times requires comparison of two matrices. Suppose fathers and sons can be found in either of two

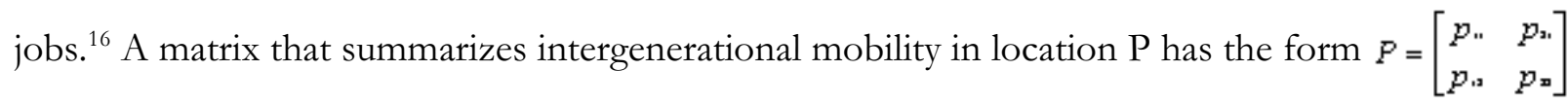
with fathers' occupations (1 or 2) as columns and sons' occupations (1 or 2 ) as rows. The entry in the upper left $\left(\mathrm{p}_{11}\right)$ is the number of sons of job 1 fathers who themselves obtained job 1 . One simple measure of the overall mobility in $\mathrm{P}$ is the fraction of sons who end up in jobs different from those of their fathers: $\mathrm{M}_{\mathrm{P}}=\left(\mathrm{p}_{12}+\mathrm{p}_{21}\right) /\left(\mathrm{p}_{11}+\mathrm{p}_{21}+\mathrm{p}_{12}+\mathrm{p}_{22}\right)$.

\footnotetext{
${ }^{15}$ We are in the process of creating additional British (1881-1901) and U.S. (1900-1920) data with twenty year intervals.

${ }^{16}$ No ordering can be imposed on the occupations. When we turn to analysis of the nineteenth century data with four categories (white collar, farmer, skilled/semi-skilled, and unskilled), it is possible to rank unskilled last unambiguously, but it is not clear how to rank the others relative to unskilled. There are no good sources that would allow us to calculate avera ge incom es by occupation. We thus require analysis techniques that rely not on the ordering of occupational categories but only on their labeling.
} 
Though this measure has the virtue of simplicity as a benchmark, it also has a shortcoming when mobility is compared across two matrices P and Q: it does not distinguish between differences in mobility (1) arising from differences across the matrices in the distributions of fathers' and sons' occupations (differences in what Hauser, 1980, labels "prevalence") and (2) arising from differences across the matrices in the association between father's and sons' jobs that may occur even if the distributions of fathers' and sons' occupations were identical in P and Q (differences in what Hauser, 1980, calls "interaction"). Consider $P=\left[\begin{array}{cc}10 & 5 \\ 5 & 10\end{array}\right]$ and $Q=\left[\begin{array}{cc}20 & 20 \\ 5 & 20\end{array}\right]$ for which $\mathrm{M}_{\mathrm{P}}=10 / 30$ and $\mathrm{M}_{\mathrm{Q}}=25 / 65$. The marginal frequencies differ, so it is not clear whether the difference in observed mobility $\mathrm{M}$ results from this difference or from something more fundamental such as differences between $\mathrm{P}$ and Q in the amount of human capital necessary to achieve job 1 .

One way to proceed is to adjust one of the matrices so it has the same marginal frequencies as the other. Such a transformation, if achieved by multiplication of rows and columns by appropriate constants, does not alter the underlying mobility embodied in the matrix. (Mosteller, 1968; Altham and Ferrie, 2005) If we were to multiply the first row of Q by $1 / 2$ and then multiply the second column of the resulting matrix by $1 / 2$, we would produce a new matrix $Q^{\prime}$ with the same marginal frequencies as in matrix $\mathrm{P}$, with an associated total mobility measure $\mathrm{M}_{\mathrm{Q}^{\prime}}$. We could then calculate the difference $\mathrm{M}_{\mathrm{P}}-\mathrm{M}_{\mathrm{Q}^{\prime}}$ and be confident that the difference in mobility does not result from differences in the distributions of occupations between the two locations.

There still may be differences in mobility between $\mathrm{P}$ and $\mathrm{Q}$, even after adjusting the marginal frequencies and finding that $\mathrm{M}_{\mathrm{P}}-\mathrm{M}_{\mathrm{Q}^{\prime}}=0$, however. The fundamental measure of association between rows and columns in a mobility table is the cross-product ratio, which for $\mathrm{P}$ is $\mathrm{p}_{11} \mathrm{p}_{22} / \mathrm{p}_{12} \mathrm{P}_{21}$ and can be rearranged to give $\left(\mathrm{p}_{11} / \mathrm{p}_{12}\right) /\left(\mathrm{p}_{21} / \mathrm{p}_{22}\right)$, the ratio of $(1)$ the odds that sons of job 1 fathers get job 1 rather than job 2 to (2) the odds that sons of job 2 fathers get job 1 rather than job 2 . If 
there is perfect mobility, the cross-product ratio would be one: sons of job 1 fathers would have no advantage in getting job1 relative to sons of job 2 fathers. The more the cross-product ratio exceeds one, the greater the relative advantage of having a job 1 father in getting job 1 . The cross-product ratio for both $\mathrm{P}$ and $\mathrm{Q}$ is 4, so these matrices have the same underlying mobility.

For a table with more than two rows or columns, there are several cross-products ratios, so a summary measure of association should take account of the full set of them. One such measure has been suggested by Altham (1970): the sum of the squares of the differences between the logs of the cross-product ratios in tables $\mathrm{P}$ and $\mathrm{Q}$. For two tables which each have $\mathrm{r}$ rows and s columns, it measures how far the association between rows and columns in table P departs from the association between rows and columns in table Q:

$d(P, Q)=\left[\sum_{i=1}^{r} \sum_{j=1}^{s} \sum_{l=1}^{r} \sum_{m=1}^{s} \mid \log \left(\frac{p_{i j} p_{i m} D_{i m} D_{l}}{p_{i m} D_{i} q_{i j} G_{l m}}\right)^{2}\right]^{1 / 2}$

The metric $\mathrm{d}(\mathrm{P}, \mathrm{Q})$ tells us the distance between tables $\mathrm{P}$ and $\mathrm{Q} \cdot{ }^{17} \mathrm{~A}$ simple likelihood-ratio $\chi^{2}$ statistic $\mathrm{G}^{2}$ (Agresti, 2002, p. 140) with (r-1)(s-1) degrees of freedom can then be used to test whether the matrix $\Theta$ with elements $\theta_{\mathrm{ij}}=\log \left(\mathrm{p}_{\mathrm{ij}} / \mathrm{q}_{\mathrm{ij}}\right)$ is independent; if we can reject the null hypothesis that $\Theta$ is independent, we essentially accept the hypothesis that $d(P, Q) \neq 0$ so the degree of association between rows and columns differs between table P and table Q. The statistic does not tell us which table has the stronger association, but that can be determined by calculating $\mathrm{d}(\mathrm{P}, \mathrm{I})$ and $\mathrm{d}(\mathrm{Q}, \mathrm{I})$, which use the same formula as $\mathrm{d}(\mathrm{P}, \mathrm{Q})$ but replace one table with a matrix of ones. If $\mathrm{d}(\mathrm{P}, \mathrm{Q})>0$ and $\mathrm{d}(\mathrm{P}, \mathrm{I})>\mathrm{d}(\mathrm{Q}, \mathrm{I})$, we can safely conclude that mobility is greater in table $\mathrm{Q}$ (i.e. mobility

\footnotetext{
17 See Altham and Ferrie (2005) for a discussion of the distance measure and test statistic, and for algorithms for their computation.
} 
is closer in Q than in P to what we would observe under independence of rows and columns, in which the occupation of a father provides no information in predicting the occupation of his son).

Contingency tables are often dominated by elements along the main diagonal (which in the case of mobility captures immobility or occupational inheritance). It will prove useful to calculate an additional version of $\mathrm{d}(\mathrm{P}, \mathrm{Q})$ that examines only the off-diagonal cells to see whether, conditional on occupational mobility occurring between fathers and sons, the resulting patterns of mobility are similar in $\mathrm{P}$ and $\mathrm{Q}$. This new statistic will then test whether $\mathrm{P}$ and $\mathrm{Q}$ differ in their proximity to “quasi-independence.” (Agresti, 2002, p. 426) For square contingency tables with r rows and columns, this additional statistic $\mathrm{d}^{\mathrm{i}}(\mathrm{P}, \mathrm{Q})$ will have the same properties as $\mathrm{d}(\mathrm{P}, \mathrm{Q})$, but the likelihood ratio $\chi^{2}$ statistic $G^{2}$ will have $\left[(r-1)^{2}-r\right]$ degrees of freedom.

Because it is a pure function of the odds ratios in tables $P$ and $Q, d(P, Q)$ is invariant to the multiplication of rows or columns in either table by arbitrary constants. As a result, d(P,Q) provides a measure of the difference in row-column association between two tables that abstracts from differences in marginal frequencies. Because $[\mathrm{d}(\mathrm{P}, \mathrm{Q})]^{2}$ is a simple sum of the squares of $\log$ odds ratio contrasts, it can be conveniently decomposed into its constituent elements: for an $\mathrm{r} \times \mathrm{s}$ table, there will be $[\mathrm{r}(\mathrm{r}-1) / 2][\mathrm{s}(\mathrm{s}-1) / 2]$ odds ratios in $\mathrm{d}(\mathrm{P}, \mathrm{Q})$ and it will be possible to calculate how much each contributes to $[\mathrm{d}(\mathrm{P}, \mathrm{Q})]^{2}$, in the process identifying the locations in $\mathrm{P}$ and $\mathrm{Q}$ where the differences between them are greatest.

In analyzing how mobility differs between two tables, we will then proceed in three steps: 1. calculate total mobility for each table as the ratio of the sum of the off-diagonal elements to the total number of observations in the table, and find the difference in total mobility between P and Q;

2. adjust one of the tables to have the same marginal frequencies as the other and re-calculate the difference in total mobility to eliminate the influence of differences in the distribution of occupations; 
3. calculate $d(P, Q), d^{i}(P, Q), d(P, I)$, and $d(Q, I)$ and the likelihood ratio $\chi^{2}$ statistics $\mathrm{G}^{2}$; if $d(P, Q) \neq 0$, calculate the full set of $\log$ odds ratio contrasts and identify those making the greatest contribution to $[\mathrm{d}(\mathrm{P}, \mathrm{Q})]^{2}$.

This differs substantially from common practice in sociology, where the estimation of loglinear models has dominated the empirical analysis of mobility since the 1960 s. ${ }^{18}$ Log-linear analysis decomposes the influences on the log of each entry in a contingency table into a sum of effects for its row and column and an interaction between the row and column. Controlling for row and column effects eliminates the effect of the distribution of fathers' and sons' occupations on mobility. The remaining interaction between rows and columns captures the strength of the association between rows and columns which in turn measures mobility, though the coefficient on the interaction term has no meaning in itself as it is a component of a highly non-linear system. In comparing mobility in two tables, attention is generally focused on the statistical significance of the difference in the interaction effect rather than on its magnitude. In addition, a simple comparison of differences in the interaction term is seldom performed without the imposition of additional structure. For example, it might be supposed that all of the odds ratios in P differ in exactly the same degree from all of the odds ratios in $\mathrm{Q}$, or that the odds ratios can be partitioned into sets that differ uniformly across the tables.

This results in a bewildering number of specifications, and may account for some of the conflicting findings even in the use of identical data sets when mobility rates are compared for modern economies (Britain has been shown to have the same mobility as the U.S., less mobility than the U.S., and more mobility than the U.S.). The measure of underlying mobility adopted here (1) relies on fewer assumptions, (2) by construction, abstracts from differences in mobility arising from differences across the tables in the distributions of occupation, (3) generates a simple, meaningful

\footnotetext{
${ }^{18}$ See Hauser (1980).
} 
measure of the distance between the row and column association in $\mathrm{P}$ and the row and column association in Q, and (4) allows us to isolate the specific odds ratios that account for the largest part of difference between the association in $\mathrm{P}$ and the association in $\mathrm{Q}$.

\section{Britain vs. the U.S. in the Twentieth Cen tury}

Before turning to the nineteenth century, we assess the difference in mobility between Britain and the U.S. using the tools described in the previous section. We have used males age 31-37 in 1972 from the Oxford Mobility Study and white, native-born males age 33-39 in 1973 from the Occupational Change in a Generation survey. These ages were chosen to avoid the influence of the Great Depression. All cases in which the respondent reported a non-civilian occupation for himself or his father were excluded. Table 1 provides a cross-classification of son's occupation by father's occupation, and Table 2 provides summary measures of mobility for each panel in Table 1 and for differences in mobility between the panels.

According to the simple measure of total mobility M, young men in their thirties in 1972-73 were less likely in the U.S. than in Britain to find themselves in the occupations their fathers had in 1949-55. But this difference was largely a result of differences in the occupational structures of the two economies. If total mobility is measured using either the British or U.S. distributions of occupations, the gap in total mobility falls from 11.4 percentage points to 3 percentage points. If Britain had the U.S. occupational distribution but the underlying association between rows and columns actually seen in Britain, and the U.S. had the British occupational distribution but the underlying association between rows and columns actually seen in the U.S., the British (53.7 percent) would have actually had more total mobility than the U.S. (48.3 percent). 


\begin{tabular}{|c|c|c|c|c|c|}
\hline \multicolumn{6}{|c|}{ Father's Occupation } \\
\hline Son's Occupation & $\begin{array}{l}\text { White } \\
\text { Collar }\end{array}$ & Farmer & $\begin{array}{c}\text { Skilled/ } \\
\text { Semiskilled }\end{array}$ & Unskilled & Row Sum \\
\hline \multicolumn{6}{|l|}{ Britain (Table P): } \\
\hline White Collar & $\begin{array}{l}174.0 \\
(68.2)\end{array}$ & $\begin{array}{c}11.0 \\
(25.6)\end{array}$ & $\begin{array}{l}206.0 \\
(30.7)\end{array}$ & $\begin{array}{c}38.0 \\
(24.5)\end{array}$ & 429.0 \\
\hline Farmer & $\begin{array}{c}2.0 \\
(0.8)\end{array}$ & $\begin{array}{c}9.0 \\
(20.9)\end{array}$ & $\begin{array}{c}3.0 \\
(0.4)\end{array}$ & $\begin{array}{c}1.0 \\
(0.6)\end{array}$ & 15.0 \\
\hline Skilled/Semiskilled & $\begin{array}{c}71.0 \\
(27.8)\end{array}$ & $\begin{array}{c}19.0 \\
(44.2)\end{array}$ & $\begin{array}{l}417.0 \\
(62.2)\end{array}$ & $\begin{array}{l}102.0 \\
(65.8)\end{array}$ & 609.0 \\
\hline Unskilled & $\begin{array}{c}8.0 \\
(3.1)\end{array}$ & $\begin{array}{c}4.0 \\
(9.3)\end{array}$ & $\begin{array}{l}44.0 \\
(6.6)\end{array}$ & $\begin{array}{l}14.0 \\
(9.0)\end{array}$ & 70.0 \\
\hline Column Sum & 255.0 & 43.0 & 670.0 & 155.0 & 1123.0 \\
\hline U.S. (Table Q): & & & & & \\
\hline White Collar & $\begin{array}{l}595.0 \\
(71.4)\end{array}$ & $\begin{array}{l}144.0 \\
(31.9)\end{array}$ & $\begin{array}{l}539.0 \\
(43.6)\end{array}$ & $\begin{array}{l}164.0 \\
(35.1)\end{array}$ & 1442.0 \\
\hline Farmer & $\begin{array}{c}3.0 \\
(0.4)\end{array}$ & $\begin{array}{c}61.0 \\
(13.5)\end{array}$ & $\begin{array}{c}7.0 \\
(0.6)\end{array}$ & $\begin{array}{c}5.0 \\
(1.1)\end{array}$ & 76.0 \\
\hline Skilled/Semiskilled & $\begin{array}{l}186.0 \\
(22.3)\end{array}$ & $\begin{array}{l}193.0 \\
(42.8)\end{array}$ & $\begin{array}{l}576.0 \\
(46.6)\end{array}$ & $\begin{array}{l}236.0 \\
(50.5)\end{array}$ & 1191.0 \\
\hline Unskilled & $\begin{array}{l}49.0 \\
(5.9)\end{array}$ & $\begin{array}{c}53.0 \\
(11.8)\end{array}$ & $\begin{array}{r}115.0 \\
(9.3)\end{array}$ & $\begin{array}{c}62.0 \\
(13.3)\end{array}$ & 279.0 \\
\hline Column Sum & 833.0 & 451.0 & 1237.0 & 467.0 & 2988.0 \\
\hline
\end{tabular}

Table 1. Intergenerational Occupational Mobility in Britain and the U.S., 1949-55 to 1972-73, Males 31-37 (Britain) and 33-39 (U.S.) in Terminal Year. Frequencies (Column Percent).

In both Britain and the U.S., an underlying association between fathers' and sons' occupations apart from that induced by differences in occupational distributions was present (for both, we can reject the null hypothesis that their association between rows and columns was the same as we would observe under independence). The difference between them in their degrees of association is small in magnitude (7.9), and we cannot reject at any conventional significance level the null hypothesis that their associations are identical. This is not solely the result of strong similarities in the tendency of sons to inherit their fathers' occupations, as we cannot reject the null hypothesis that association is identical even if we focus only on the off-diagonal elements in each table. These results confirm the findings of Erickson and Goldthorpe (1992) and Kerckhoff et al. 


\begin{tabular}{|c|c|c|c|c|c|c|c|c|c|c|}
\hline Comparison & $\begin{array}{l}\mathrm{M} \\
(1) \\
\end{array}$ & $\begin{array}{l}M^{\prime} \\
(2) \\
\end{array}$ & $\begin{array}{c}\mathrm{d}(\mathrm{P}, \mathrm{I}) \\
(3) \\
\end{array}$ & $\begin{array}{l}G^{2} \\
(4) \\
\end{array}$ & $\begin{array}{c}\mathrm{d}(\mathrm{Q}, \mathrm{I}) \\
(5)\end{array}$ & $\begin{array}{l}G^{2} \\
(6) \\
\end{array}$ & $\begin{array}{c}\mathrm{d}(\mathrm{P}, \mathrm{Q}) \\
(7)\end{array}$ & $\begin{array}{l}\mathrm{G}^{2} \\
(8) \\
\end{array}$ & $\begin{array}{c}\mathrm{d}^{\mathrm{i}}(\mathrm{P}, \mathrm{Q}) \\
(9)\end{array}$ & $\begin{array}{l}\mathrm{G}^{2} \\
(10)\end{array}$ \\
\hline 1. Britain $1972(\mathrm{P})$ & 45.3 & 53.7 & 24.0 & $168.4 * * *$ & & & & & & \\
\hline vs. U.S. 1973 (Q) & 56.7 & 48.3 & & & 20.8 & $420.4^{* * *}$ & 7.9 & 7.5 & 7.2 & 2.4 \\
\hline 2. Britain $1881(\mathrm{P})$ & 43.0 & 35.5 & 23.7 & $836.6^{* * *}$ & & & & & & \\
\hline vs. U.S. 1880 (Q) & 45.4 & 48.5 & & & 11.9 & $287.2^{* * *}$ & 14.4 & $108.9 * * *$ & 5.9 & $11.2^{* *}$ \\
\hline 3. U.S. $1880(\mathrm{P})$ & 50.6 & 57.7 & 12.1 & $385.4^{* * *}$ & & & & & & \\
\hline vs. U.S. 1973 (Q) & 56.7 & 43.7 & & & 20.8 & $420.4 * * *$ & 10.7 & $46.7 * * *$ & 2.4 & 3.2 \\
\hline 4. U.S. $1900(\mathrm{P})$ & 54.0 & 54.1 & 14.6 & $545.4^{* * *}$ & & & & & & \\
\hline vs. U.S. 1973 (Q) & 56.7 & 51.8 & & & 20.8 & $420.4 * * *$ & 9.1 & $36.7 * * *$ & 2.4 & 3.9 \\
\hline
\end{tabular}

Table 2. Summary Measures of Mobility in Britain and the U.S.

(1985) that, after accounting for differences in their occupational distributions, Britain and the U.S. exhibited similar intergenerational occupational mobility in the third quarter of the twentieth century.

\section{Britain vs. the U.S. in the Nineteenth Century}

How different were Britain and the U.S. in intergenerational occupational mobility a century earlier? Table 3 presents the cross-classification of sons' and father's occupations using our new data linking fathers in 1850 (U.S.) or 1851 (Britain) and sons in 1880 (U.S.) or 1881 (Britain). Summary mobility measures again appear in Table 2 . The simplest measure of mobility shows the U.S. with a slight advantage (inheritance of the father's occupation was 2.4 percentage points less likely in the 


\begin{tabular}{|c|c|c|c|c|c|}
\hline \multirow[b]{2}{*}{ Son's Occupation } & \multicolumn{4}{|c|}{$\underline{\text { Father's Occupation }}$} & \multirow[b]{2}{*}{ Row Sum } \\
\hline & $\begin{array}{l}\text { White } \\
\text { Collar }\end{array}$ & Farmer & $\begin{array}{c}\text { Skilled/ } \\
\text { Semiskilled }\end{array}$ & Unskilled & \\
\hline \multicolumn{6}{|l|}{ Britain (Table P): } \\
\hline White Collar & $\begin{array}{l}124.0 \\
(36.6)\end{array}$ & $\begin{array}{c}31.0 \\
(11.1)\end{array}$ & $\begin{array}{c}223.0 \\
(13.9)\end{array}$ & $\begin{array}{l}46.0 \\
(5.4)\end{array}$ & 424.0 \\
\hline Farmer & $\begin{array}{l}10.0 \\
(2.9)\end{array}$ & $\begin{array}{l}114.0 \\
(40.9)\end{array}$ & $\begin{array}{l}38.0 \\
(2.4)\end{array}$ & $\begin{array}{l}20.0 \\
(2.3)\end{array}$ & 182.0 \\
\hline Skilled/Semiskilled & $\begin{array}{l}175.0 \\
(51.6)\end{array}$ & $\begin{array}{l}91.0 \\
(32.6)\end{array}$ & $\begin{array}{r}1119.0 \\
(69.6)\end{array}$ & $\begin{array}{l}391.0 \\
(45.6)\end{array}$ & 1776.0 \\
\hline Unskilled & $\begin{array}{l}30.0 \\
(8.8)\end{array}$ & $\begin{array}{c}43.0 \\
(15.4)\end{array}$ & $\begin{array}{l}227.0 \\
(14.1)\end{array}$ & $\begin{array}{l}400.0 \\
(46.7)\end{array}$ & 700.0 \\
\hline Column Sum & 339.0 & 279.0 & 1607.0 & 857.0 & 3082.0 \\
\hline U.S. (Table Q): & & & & & \\
\hline White Collar & $\begin{array}{c}55.0 \\
(38.5)\end{array}$ & $\begin{array}{l}177.0 \\
(12.9)\end{array}$ & $\begin{array}{l}82.0 \\
(22.6)\end{array}$ & $\begin{array}{c}30.0 \\
(23.3)\end{array}$ & 344.0 \\
\hline Farmer & $\begin{array}{c}44.0 \\
(30.8)\end{array}$ & $\begin{array}{l}850.0 \\
(62.0)\end{array}$ & $\begin{array}{c}92.0 \\
(25.3)\end{array}$ & $\begin{array}{c}35.0 \\
(27.1)\end{array}$ & 1021.0 \\
\hline Skilled/Semiskilled & $\begin{array}{c}33.0 \\
(23.1)\end{array}$ & $\begin{array}{l}214.0 \\
(15.6)\end{array}$ & $\begin{array}{l}166.0 \\
(45.7)\end{array}$ & $\begin{array}{c}40.0 \\
(31.0)\end{array}$ & 453.0 \\
\hline Unskilled & $\begin{array}{l}11.0 \\
(7.7)\end{array}$ & $\begin{array}{r}129.0 \\
(9.4)\end{array}$ & $\begin{array}{c}23.0 \\
(6.3)\end{array}$ & $\begin{array}{c}24.0 \\
(18.6)\end{array}$ & 187.0 \\
\hline Column Sum & 143.0 & 1370.0 & 363.0 & 129.0 & 2005.0 \\
\hline
\end{tabular}

Table 3. Intergenerational Occupational Mobility in Britain and the U.S., 1850-51 to 1880-81, Males 43-49 in Terminal Year. Frequencies (Column Percent).

U.S.), but substantial differences in occupational distributions obscure much larger differences. If the U.S. had Britain's occupational distribution, the U.S. advantage in total mobility would have been 5.5 percentage points; if Britain had the U.S. distribution, the U.S. advantage would have been 9.9 percentage points. Finally, if Britain and the U.S. had swapped occupational distributions and retained their underlying association between fathers' and sons' occupations, the U.S. advantage would have been 13 percentage points.

These simple comparisons suggest that more fundamental measures of association between fathers' and sons' occupations would reveal a weaker association (and greater mobility) in the U.S. The second set of summary mobility measures in Table 2 shows that this was indeed the case: 
though the association between fathers' and sons' occupations differed from independence in Britain and the U.S., the magnitude of the association was twice as great in Britain as in the U.S. We can safely reject the null hypothesis that the difference between them in their associations was actually zero. The point estimate for $\mathrm{d}(\mathrm{P}, \mathrm{Q})$ was 14.4 , indicating a difference in mobility after controlling for occupational distributions that was not only statistically significant but also large in a substantive sense.

Table 4 disaggregates $[\mathrm{d}(\mathrm{P}, \mathrm{Q})]^{2}$ into its components, and calculates the contribution of each of the $\left[\mathrm{d}_{\mathrm{i}}(\mathrm{P}, \mathrm{Q})\right]^{2}$ that account for three quarters of $[\mathrm{d}(\mathrm{P}, \mathrm{Q})]^{2}$ to the total. $\mathrm{G}^{2}$ is also reported for each contrast, as well as the underlying odds ratios from P and Q. For example, the first entry is the relative advantage in entering farming rather than unskilled work from having a farmer father rather than an unskilled father. In Britain, sons of farmers were 53 times more likely to enter farming rather than unskilled work than were the sons of unskilled workers. In the U.S., the ratio was only 4.5 to one, so the advantage of having a farm father rather than an unskilled father in making this move (into farming rather than unskilled work) was more than 11 times greater in Britain than in the U.S. This odds ratio contrast alone accounts for nearly 12 percent of the difference between the association in $\mathrm{P}$ and the association in $\mathrm{Q}$. Of the eleven odds ratios that account for 75 percent of the difference in association between $\mathrm{P}$ and $\mathrm{Q}$, six display a smaller disadvantage in the U.S. in entering farming rather than another occupation for the sons of non-farmers, indicating that an important source of greater intergenerational mobility in the U.S. than in Britain was an easier path 


\begin{tabular}{|c|c|c|c|c|c|c|c|c|c|c|}
\hline Contrast & $\mathrm{d}(\mathrm{P}, \mathrm{I})$ & $\begin{array}{l}\text { Odds } \\
\text { Ratio }\end{array}$ & $\mathrm{G}^{2}$ & $\mathrm{~d}(\mathrm{Q}, \mathrm{I})$ & $\begin{array}{l}\text { Odds } \\
\text { Ratio }\end{array}$ & $\mathrm{G}^{2}$ & $\mathrm{~d}(\mathrm{P}, \mathrm{Q})$ & $\mathrm{G}^{2}$ & $\begin{array}{c}\text { Pct. of } \\
\text { Total }\end{array}$ & $\begin{array}{c}\text { Cumulative } \\
\text { Percent }\end{array}$ \\
\hline$\overline{[(\mathrm{FF}) /(\mathrm{FU})] /[(\mathrm{UF}) /(\mathrm{UU})]}$ & 7.94 & 53.02 & $280.27 * * *$ & 3.02 & 4.52 & $25.30^{* * *}$ & 4.93 & $40.18^{* * *}$ & 11.6 & 11.6 \\
\hline$[(\mathrm{FF}) /(\mathrm{FU})] /[(\mathrm{SF}) /(\mathrm{SU})]$ & 5.52 & 15.84 & $149.36 * * *$ & 1.00 & 1.65 & $3.65^{*}$ & 4.53 & $45.68^{* * *}$ & 9.8 & 21.5 \\
\hline$[(\mathrm{WW}) /(\mathrm{WU})] /[(\mathrm{UW}) /(\mathrm{U} \mathrm{U})]$ & 7.16 & 35.94 & $267.33 * * *$ & 2.77 & 4.00 & $11.21 * * *$ & 4.39 & $17.30 * * *$ & 9.3 & 30.7 \\
\hline$[(\mathrm{WW}) /(\mathrm{WF})] /[(\mathrm{FW}) /(\mathrm{FF})]$ & 7.64 & 45.60 & $161.69 * * *$ & 3.58 & 6.00 & $65.49 * * *$ & 4.06 & $24.32 * * *$ & 7.9 & 38.6 \\
\hline$[(\mathrm{WF}) /(\mathrm{W} \mathrm{S})] /[(\mathrm{FF}) /(\mathrm{FS})]$ & 6.18 & 21.92 & $128.34 * * *$ & 2.18 & 2.98 & $18.80^{* * *}$ & 3.99 & $25.47^{* * *}$ & 7.7 & 46.3 \\
\hline$[(\mathrm{FW}) /(\mathrm{FU})] /[(\mathrm{UW}) /(\mathrm{UU})]$ & 3.67 & 6.27 & $39.42 * * *$ & 0.19 & 1.10 & 0.10 & 3.48 & $17.95^{* * *}$ & 5.8 & 52.1 \\
\hline$[(\mathrm{FF}) /(\mathrm{FS})] /[(\mathrm{UF}) /(\mathrm{US})]$ & 6.40 & 24.49 & $203.75^{* * *}$ & 3.03 & 4.54 & $37.08^{* * *}$ & 3.37 & $22.66^{* * *}$ & 5.5 & 57.6 \\
\hline$[(\mathrm{FF}) /(\mathrm{FS})] /[(\mathrm{SF}) /(\mathrm{SS})]$ & 7.22 & 36.89 & $337.03 * * *$ & 3.94 & 7.17 & $181.68^{* * *}$ & 3.28 & $40.55^{* * *}$ & 5.2 & 62.7 \\
\hline$[(\mathrm{FW}) /(\mathrm{FF})] /[(\mathrm{SW}) /(\mathrm{SF})]$ & 6.14 & 21.58 & $169.82^{* * *}$ & 2.91 & 4.28 & $67.65^{* * *}$ & 3.24 & $27.71 * * *$ & 5.0 & 67.8 \\
\hline$[(\mathrm{WF}) /(\mathrm{W} \mathrm{U})] /[(\mathrm{FF}) /(\mathrm{FU})]$ & 4.15 & 7.95 & $30.41 * * *$ & 1.00 & 1.65 & 1.86 & 3.15 & $9.47 * * *$ & 4.8 & 72.5 \\
\hline$[(\mathrm{WW}) /(\mathrm{WF})] /[(\mathrm{UW}) /(\mathrm{UF})]$ & 3.37 & 5.39 & $16.97 * * *$ & 0.75 & 1.46 & 1.39 & 2.61 & $6.22 * *$ & 3.3 & 75.8 \\
\hline
\end{tabular}

Table 4. Components of $d(P, I), d(Q, I)$, and $d(P, Q)$ for Britain 1851-81 (P) vs. U.S. 1850-80 (Q). First element of each pair is father's occupation, second is son's. W: White Collar, S: Skilled, F: Farmer, U: Unskilled. 
to farm ownership from outside agriculture, regardless of the distribution of occupations for fathers and sons. But the importance of farming by no means exhausts the sources of higher mobility in the U.S. For example, in Britain, white collar sons had a 36 to one advantage in entering white collar rather than unskilled jobs compared to the sons of unskilled workers; in the U.S., their advantage was only 4 to one, less than an eighth of the advantage in making this transition conveyed in Britain by having a white collar father.

\begin{tabular}{|c|c|c|c|c|c|}
\hline \multicolumn{6}{|c|}{ Father's Occupation } \\
\hline Son's Occupation & $\begin{array}{l}\text { White } \\
\text { Collar }\end{array}$ & Farmer & $\begin{array}{c}\text { Skilled/ } \\
\text { Semiskilled }\end{array}$ & Unskilled & Row Sum \\
\hline \multicolumn{6}{|l|}{ U.S. 1880 (Table P): } \\
\hline White Collar & $\begin{array}{l}115.0 \\
(46.0)\end{array}$ & $\begin{array}{l}233.0 \\
(13.8)\end{array}$ & $\begin{array}{l}115.0 \\
(25.2)\end{array}$ & $\begin{array}{c}39.0 \\
(16.5)\end{array}$ & 502.0 \\
\hline Farmer & $\begin{array}{c}43.0 \\
(17.2)\end{array}$ & $\begin{array}{l}949.0 \\
(56.2)\end{array}$ & $\begin{array}{l}103.0 \\
(22.5)\end{array}$ & $\begin{array}{c}60.0 \\
(25.3)\end{array}$ & 1155.0 \\
\hline Skilled/Semiskilled & $\begin{array}{c}59.0 \\
(23.6)\end{array}$ & $\begin{array}{l}286.0 \\
(16.9)\end{array}$ & $\begin{array}{l}173.0 \\
(37.9)\end{array}$ & $\begin{array}{c}75.0 \\
(31.6)\end{array}$ & 593.0 \\
\hline Unskilled & $\begin{array}{c}33.0 \\
(13.2)\end{array}$ & $\begin{array}{l}220.0 \\
(13.0)\end{array}$ & $\begin{array}{c}66.0 \\
(14.4)\end{array}$ & $\begin{array}{c}63.0 \\
(26.6)\end{array}$ & 382.0 \\
\hline Column Sum & 250.0 & 1688.0 & 457.0 & 237.0 & 2632.0 \\
\hline
\end{tabular}

Table 5. Intergenerational Occupational Mobility in the U.S., 1860-80, Males 33-39 in Terminal Year. Frequencies (Column Percent).

Not only is overall mobility greater in the U.S., but upward mobility also exceeds that in Britain. Without a comparable scheme of fully ranked occupational categories for both countries, a complete analysis of upward and downward mobility is impossible. However, some conclusions follow from innocuous assumptions. Assuming that unskilled occupations are less desirable than all others, Table 3 indicates that in the U.S. 81.4 percent of all sons of unskilled laborers moved up into other occupations, while only 53.3 percent of unskilled British sons experienced upward mobility; if the British marginal distribution of occupations is imposed on the U.S. mobility table, the U.S. 
advantage is narrowed but not eliminated (upward mobility in the U.S. falls to 62.2 percent, compared to 53.3 percent in Britain), while if the U.S. marginal distribution of occupations is imposed on the British mobility table, the British disadvantage is narrowed slightly but remains large (upward mobility in Britain rises to 58.7 percent, compared to 81.4 percent in the U.S.). Downward mobility in the U.S. was lower than in Britain: 8.7 percent moved into unskilled labor in the U.S. versus 13.5 percent in Britain, though this difference is reversed if either the British or U.S. marginal distributions are used for both countries. The U.S. was not only a less static labor market than Britain, but also a labor market with better prospects for upward movement even after accounting for differences between its occupational structure and Britain's. Observed downward mobility was also less frequent in the U.S. than in Britain, but would have been slightly greater in the U.S. than in Britain if the two countries had the same marginal distributions of occupation.

\section{Nineteenth Century vs. Twentieth Century Mobility in the U.S.}

The difference in mobility between Britain and the U.S. in the nineteenth century was substantial, both be fore and after taking account of differences in their distributions of occupations. We have already seen that Britain and the U.S. were indistinguishable in terms of intergenerational occupational mobility in the third quarter of the twentieth century, after taking account of their occupational distributions. How was this convergence in underlying mobility achieved? Did U.S. mobility fall or did British mobility rise to U.S. levels? We cannot directly assess the change over time in British mobility in the absence of nineteenth century longitudinal data that span twenty years, unless we were to include the Great Depression. For the U.S. however, we have samples that span 1860-80 and 1880-1900 that are identical in their construction to the 1850-80 sample we used in the comparison to Britain 1851-81. Males age 33-39 at the end of the 1860-80 and 1880-1900 U.S. samples can be compared to males age 33-39 in the 1973 cohort of the OCG. These samples then 
both span either exactly 20 years between fathers' and sons occupations (1860 to 1880 and 1880 to 1900) or an average of 20 years between fathers' and sons' occupations (1949-55 to 1973). Table 5 presents the cross-classification of fathers' and sons' occupations for the 1860-80 data, which are compared to the OCG data from the lower panel of Table 1. Summaries of the comparison between them appear in the third set of contrasts in Table 2.

Total mobility shows a 6.1 percentage point advantage for the modern data, but when it is calculated for both tables using common marginal frequencies, the nineteenth century table has higher total mobility, by from one (using the 1860-80 frequencies) to 6.9 percentage points (using the 1973 frequencies). If the marginal frequencies are swapped but the underlying associations are left unchanged, the nineteenth century U.S. had a total mobility rate 1.3 times greater than that in the 1949-73 period. The more fundamental measure of mobility, $d(P, Q)$, also shows greater mobility (i.e. a weaker association between fathers' and sons' occupations) in the nineteenth century than in the twentieth: we can safely reject the null hypothesis that the associations are equal $\left(G^{2}=46.7\right.$ on 9 degrees of freedom, probability $\left(\mathrm{H}_{0}\right.$ : same association $\left.)<0.0001\right)$, and the difference $\mathrm{d}(\mathrm{P}, \mathrm{Q})$ is large in magnitude. We cannot, however, reject the hypothesis that the associations are identical when the diagonal elements in $\mathrm{P}$ and $\mathrm{Q}$ are excluded, suggesting that change in the likelihood of direct inheritance of the father's occupational status by the son was the greatest difference between these eras, rather than more subtle change in the structure of association between one generation's occupation and that of the next.

Table 6 decomposes the elements of $d(P, Q)$ into those that account for three quarters of the difference between mobility in the nineteenth century and mobility in the twentieth. The single greatest difference - making up nearly 15 percent of the difference between the association in the nineteenth century and association in the twentieth - is in the upper left four cells of the 
contingency table. In the nineteenth century, getting a white collar rather than farm job was 11 times more likely for the son of a white collar worker than for the son of a farmer; by the twentieth century, the advantage of white collar sons had grown nearly eight-fold relative to farm sons in getting white collar jobs rather than farm jobs. The second and third contrasts in Table 6 show swings in the odds ratios of similar magnitude from the nineteenth to the twentieth centuries (the advantage of farm sons relative to skilled and semiskilled sons in getting (1) white collar rather than farm jobs, and (2) farm jobs rather than unskilled jobs). Of the seven substantial differences between the nineteenth and twentieth centuries, three provide evidence of greater difficulty entering white collar jobs (for the sons of farmers relative to sons of white collar workers, for the sons of skilled workers relative to sons of farmers, and for sons of unskilled workers relative to sons of farmers).

The difference between nineteenth and twentieth century mobility persists into the last two decades of the nineteenth century. If the 1880-1900 sample is used $(\mathrm{P})$ and compared to the 1973 OCG cohort (Q), substantially more mobility is again observed in the historical data than in the more recent past. Contrast 4 in Table 2 shows these results: total mobility was greater in the past if the nineteenth century occupational distributions are used or if the occupational distributions are swapped and each period retains its actual association between fathers' and sons' occupations. The unadjusted total mobility and total mobility using the twentieth century frequencies, however, favor 


\begin{tabular}{|c|c|c|c|c|c|c|c|c|c|c|}
\hline Contrast & $\mathrm{d}(\mathrm{P}, \mathrm{I})$ & $\begin{array}{l}\text { Odds } \\
\text { Ratio }\end{array}$ & $\mathrm{G}^{2}$ & $\mathrm{~d}(\mathrm{Q}, \mathrm{I})$ & $\begin{array}{l}\text { Odds } \\
\text { Ratio }\end{array}$ & $\mathrm{G}^{2}$ & $\mathrm{~d}(\mathrm{P}, \mathrm{Q})$ & $\mathrm{G}^{2}$ & $\begin{array}{c}\text { Pct. of } \\
\text { Total }\end{array}$ & $\begin{array}{c}\text { Cumulative } \\
\text { Percent }\end{array}$ \\
\hline$\overline{[(\mathrm{WW}) /(\mathrm{WF})] /[(\mathrm{FW}) /(\mathrm{FF})]}$ & 4.78 & 10.89 & $176.51 * * *$ & 8.86 & 84.02 & $159.17 * * *$ & 4.09 & $16.29 * * *$ & 14.7 & 14.7 \\
\hline$[(\mathrm{FW}) /(\mathrm{FF})] /[(\mathrm{SW}) /(\mathrm{SF})]$ & 3.03 & 4.55 & $95.11 * * *$ & 6.97 & 32.62 & $131.80^{* * *}$ & 3.94 & $27.39 * * *$ & 13.7 & 28.3 \\
\hline$[(\mathrm{FF}) /(\mathrm{FU})] /[(\mathrm{SF}) /(\mathrm{SU})]$ & 2.03 & 2.76 & $31.77 * * *$ & 5.88 & 18.91 & $72.34 * * *$ & 3.85 & $21.52^{* * *}$ & 13.0 & 41.4 \\
\hline$[(\mathrm{WF}) /(\mathrm{W} \mathrm{U})] /[(\mathrm{FF}) /(\mathrm{FU})]$ & 2.39 & 3.31 & $22.33 * * *$ & 5.87 & 18.80 & $40.93^{* * *}$ & 3.47 & $8.93^{* * *}$ & 10.6 & 52.0 \\
\hline$[(\mathrm{FW}) /(\mathrm{FF})] /[(\mathrm{UW}) /(\mathrm{UF})]$ & 1.95 & 2.65 & $18.42 * * *$ & 5.26 & 13.89 & $53.91 * * *$ & 3.32 & $12.80^{* * *}$ & 9.7 & 61.6 \\
\hline$[(\mathrm{FF}) /(\mathrm{FS})] /[(\mathrm{SF}) /(\mathrm{SS})]$ & 3.44 & 5.57 & $154.21 * * *$ & 6.52 & 26.01 & $115.85^{* * *}$ & 3.08 & $16.58^{* * *}$ & 8.4 & 70.0 \\
\hline$[(\mathrm{WF}) /(\mathrm{W} \mathrm{S})] /[(\mathrm{FF}) /(\mathrm{FS})]$ & 3.03 & 4.55 & $51.26 * * *$ & 5.95 & 19.60 & $55.06^{* * *}$ & 2.92 & $7.15^{* * *}$ & 7.5 & 77.5 \\
\hline
\end{tabular}

Table 6. Components of $d(P, I), d(Q, I)$, and d(P,Q) for U.S. 1860-80 (P) vs. U.S. 1973 (Q). 
the more recent data. But the underlying association measured by $d(P, I), d(Q, I)$, and $d(P, Q)$ was substantially greater in the past than more recently. We can safely reject the hypothesis that the association was identical $\left(\mathrm{G}^{2}=36.7\right.$ on 9 degrees of freedom, probability $\left(\mathrm{H}_{0}\right.$ : same association $)<$ 0.0001). Even in the last two decades of the nineteenth century, mobility was greater than in the 1949-73 period, a difference that was both large in substance and statistically significant. High mobility in the nineteenth century U.S. was thus not principally a consequence of the enormous turnover in the U.S. labor force occasioned by the death of a substantial fraction of the working-age male population in the Civil War, or of the presence of an expanding agricultural frontier - the frontier was already "closed" by 1890 , according to the U.S. Census Office. ${ }^{19}$ It is also not the result of some peculiarity of the OCG data used for the twentieth century, as similar results are obtained when other modern surveys are employed. ${ }^{20}$

\section{Economic Sources of Declining Relative Mobility in the U.S.}

The U.S. was considerably more mobile than Britain in the nineteenth century and roughly similar in mobility in the twentieth. At least some of this convergence occurred because of declining mobility in the U.S. (as opposed to improved mobility in Britain). Unfortunately, the foregoing analysis sheds little light on the sources of either the U.S. advantage in the nineteenth century or its relative decline in mobility from the nineteenth century to the twentieth. Because the metric for the

\footnotetext{
${ }^{19}$ The Sup erintendent of the Censu s reported in 1890 that "Up to and inclu ding 1880 the country had a frontier of settlement, but at present the unsettled area has been so broken into by isolated bodies of settlement that there can hardly be said to be a frontier line. In the discussion of its extent, its westward movement, etc., it can not, therefore, any longer have a place in the census reports." (U.S. Census Office, 1891).

${ }^{20}$ Ferrie (forthcoming) includes comparisons between the nineteenth century data shown here and twentieth century data from the NLS and NLSY79. In each case, the nineteenth century displays mobility that is greater in magnitude than the twentieth century, differences that are in every case highly sta tistically significant. By contrast, differences within the twentieth century are small in magnitude and seldom statistically significant.
} 
distance in association used here focuses on odds ratios, it is not even possible to say for certain whether the observed differences result from differences in the numerators, in the denominators, or in both. ${ }^{21}$

Are the differences we have observed (between the mid-nineteenth century U.S. and either mid-nineteenth century Britain or the mid-twentieth century U.S.) simply a reflection of differences in the size of the farm sector, i.e. so many more farmers in the mid-nineteenth century U.S. and as a result much movement out of farming and more "mobility?" The measure of mobility we have used already adjusts for differences in the size of the occupation groups, however. If the mid-nineteenth century U.S. farm sector is driving the results, it must be more than the difference in the sector's sheer size generating differences with Britain at the same time or the U.S. 100 years later. There must be a selectivity effect as well.

Consider nineteenth century Britain versus the nineteenth century U.S.: Britain has already seen almost all of its flight from agriculture by 1851, so the sons of farmer fathers are already selected for remaining in farming (all the sons who were more loosely attached to the sector have already left by 1851). At the same time, the sons of non-farm fathers are already selected for remaining outside farming (all the sons eager to enter farming have already done so). In the U.S., this weeding out process has not taken place in the nineteenth century, so the U.S. has more mobility both out of and into farming that gets added onto whatever the underlying amount of

${ }^{21}$ For example, the fourth contrast in Table 4 and the first in Table $6-[(\mathrm{WW}) /(\mathrm{WF})] /[(\mathrm{FW}) /(\mathrm{FF})]-$ is the ratio of the odds of white collar sons entering white collar jobs rather than farming to the odds of farm sons entering white collar jobs rather than farming. It is greater in nineteenth century Britain and the twentieth century U.S. than in the nineteenth century U.S. But is this because the nineteenth century U.S. has (1) greater ease for farm sons in attaining white collar jobs in the nineteenth century U.S. (FW $\uparrow$ ), (2) a weaker attachment to farming among farm sons (FF $\downarrow$ ), (3) easier entry by white collar sons into farming (WF $\uparrow$ ), or (4) a weaker attachment to white collar jobs among sons of white collar workers (WW $\downarrow$ )? Or does it result from some combination of these? 
mobility would be otherwise. ${ }^{22}$ At least some of the high mobility in the nineteenth century U.S. may then result from it being at an earlier stage of development than nineteenth century Britain or the twentieth century U.S., so its farm sector was relatively larger and selective exit from farming and entry into farming were less apparent than in Britain at the same time or in the U.S. a century later. As late as 1850, 45 percent of U.S. workers were still in farming, compared to 4 percent in Britain in 1880 and 7 percent in the U.S. in 1950.

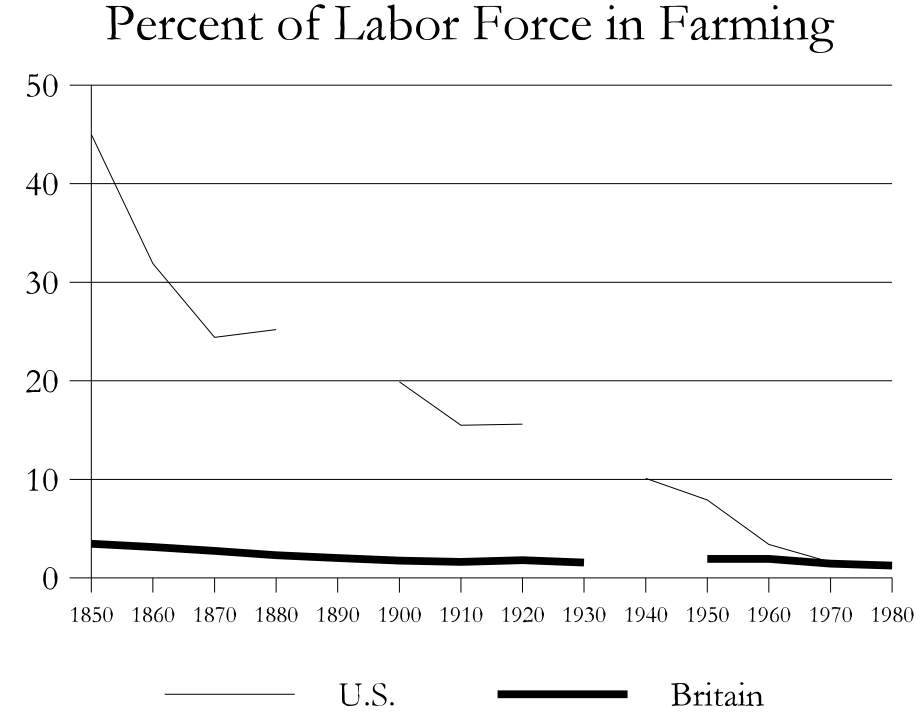

To get at the amount of mobility Figure 1. after taking out the effect of selective mobility out of or into farming, we re-ran the analyses after removing the cell Farm [father]-Farm [son] and the cells White Collar-Farm, Skilled/Semiskilled-Farm, and Unskilled-Farm. This is preferable to leaving out the farm sector altogether, as it still allows us to include the mobility of sons of farmers conditional on their departure from farming. The results are

$\mathrm{P}=$ Britain 1851-81, Q=U.S. 1850-80

$\mathrm{d}(\mathrm{P}, \mathrm{I})=15.43($ prob $<0.0001)$

$\mathrm{d}(\mathrm{Q}, \mathrm{I})=9.17($ prob $<0.0001)$

$\mathrm{d}(\mathrm{P}, \mathrm{Q})=10.03($ prob $<0.0001)$

22 Of course, for the story to work for the nineteenth century versus twentieth century U.S. case, there must be no increase in the selectivity of movement out of or into farming even as late as 1900 when farmers as a fraction of the labor force had fallen to $20 \%$ from $45 \%$ in 1850 . 
Even if we ignore the Farm-Farm immobility difference and ignore differences in entry into

farming, then, the differences in mobility still go in the same direction (the nineteenth century U.S. is markedly more mobile than nineteenth century Britain). For the U.S. over time, the same is true as well, though the remaining magnitudes are smaller:

$\mathrm{P}=$ U.S. $1860-80, \mathrm{Q}=\mathrm{U} . \mathrm{S} .1953-73$

$\mathrm{d}(\mathrm{P}, \mathrm{I})=8.32($ prob $<0.0001)$

$\mathrm{d}(\mathrm{Q}, \mathrm{I})=8.48($ prob $<0.0001)$

$\mathrm{d}(\mathrm{P}, \mathrm{Q})=3.48($ prob $<0.05)$.

Simple differences in the selectivity of exit from or entry into farming, in any case, cannot explain the majority of the contrasts in Tables 4 and $6 .{ }^{23}$ Other features of the nineteenth century U.S. economy may help explain its uniquely high rates of mobility. A useful starting point for analyzing the economic causes of differences in mobility across times or places is the formulation of Becker and Tomes (1986) who model intergenerational mobility as an outcome generated by the endowments transmitted directly from parents to children, and by investments made by parents faced with several investment opportunities and possibly constrained by the operation of capital markets from making the efficient level of investment in their children.

As Grawe and Mulligan (2002) demonstrate, this simple model provides some testable implications regarding spatial or temporal differences in eamings mobility. ${ }^{24}$ Ignoring capital

\footnotetext{
${ }^{23}$ For example, the third contrast in Table 4 does not involve farmers. The fifth contrast in Table 4 (which is also the seventh in Table 6) $-[(\mathrm{W} \mathrm{F}) /(\mathrm{WS})] /[(\mathrm{FF}) /(\mathrm{FS})]$ - can be higher in ninet eenth centu ry Britain and the twentieth century U.S. than in the nineteenth century U.S. becau se of selectivity only if exit from farming by farm sons exceeded entry by white collar sons into farming by areater margin in the nineteenth century U.S. than in either nineteenth century Britain or the twentieth century U.S. If this was not the case, differential entry into skilled and semi-skilled jobs by white collar and farm sons must also account for some of the greater size of this contrast for the nineteenth century U.S. To see this, re-write the contrast as $[(\mathrm{WF}) /(\mathrm{FF})] /[(\mathrm{WS}) /(\mathrm{FS})]$.

24 Though these implications relate to earnings mobility, it is straightforward to map them into occupational mobility. If there are two possible jobs and investment (by parents or the state) both raises (1) the odds that sons of job 1 fathers will get job 1 rather than job 2 and (2) the odd s that sons of job 2 fathers
} 
constraints (generated by the inability of parents to borrow against the future labor earnings of children), intergenerational earnings mobility will be higher when the ease with which ability is transferred to children is reduced. Han and Mulligan (2001, p. 225) show that earnings mobility is also greater when ability displays less variance. Finally, if parents are constrained in the credit market, they will invest less in their children, whose earnings will more closely reflect ability, reducing mobility. Where credit markets function well, or where wealth is greater so fewer parents find the capital constraint binding, mobility will be greater than where credit markets do not function well, or where most parents find themselves constrained by low wealth.

We have no direct evidence on how easily abilities were transmitted from parents to children in the nineteenth century in Britain and the U.S. or in the twentieth century U.S. But we can suppose that the greater heterogeneity in the origins of the U.S. population compared to the British population in the nineteenth century corresponded to greater variance in abilities in the U.S., a force working to undermine the U.S. advantage in occupational mobility relative to Britain at this time. Though we cannot test directly for the role of credit market constraints in generating the advantage enjoyed by the U.S. relative to Britain in the nineteenth century and the decline in relative mobility by the twentieth century, it is possible to see how important such impediments to investment may have been in generating the level of mobility seen within the nineteenth century U.S.

The $1860-80$ sample provides information from the 1860 population census on the total wealth owned by the household (the sum of real estate and personal estate). This makes is possible to assess the role of credit constraints by examining whether mobility differs systematically by household wealth, an indicator of the probability that a household is credit constrained. Following

will get job 1 rather than job 2, but (2) rises by more than (1), the odds ratio will fall, indicating greater mobility. The only additional assumption necessary for the implications discussed by Grawe and Mulligan (2002) to apply to occupational mobility as well is that all workers qualified for job 1 can obtain job 1. 
Mazumder (2001), the 1860-80 sample was divided in half: high total wealth families (wealth $\geq$ median wealth $=\$ 1,400$ ) and low total wealth families (wealth $<$ median). Intergenerational occupational mobility matrices were then constructed $(\mathrm{P}=$ high wealth, $\mathrm{Q}=$ low wealth), and the underlying association between fathers' and sons' occupations was calculated along with the difference in association between P and Q. For both types of households, mobility was different from that expected under independence though slightly greater in high wealth households $\left(d(P, I)=12.65, d(Q, I)=13.25\right.$, while the $G^{2}$ statistics for both are significant at 0.01 . Of greater interest is the difference in association between P and Q: $d(P, Q)=6.14\left(G^{2}=21.2\right.$, prob $\left.=0.01\right)$, confirming that mobility in the 1860s and 1870s was in fact greater among high wealth households than among low wealth households.

Grawe and Mulligan (2002, p. 51) suggest that "one way to investigate [the role of credit market imperfections] is through analysis of cross-country evidence on whether countries with greater public provision of human capital experience greater intergenerational mobility." The U.S. provided considerably more public education than Britain in the middle of the nineteenth century: the primary school enrollment rate was one and a half times greater in the U.S. than in Britain. (Easterlin, 1981, p. 7). The U.S. educational system in the second half of the nineteenth century, though less extensive at the secondary and post-secondary levels than European systems was considerably more egalitarian (Goldin, 1999, p. 2). To the extent that intergenerational mobility is greater where fewer parents are constrained, superior mobility in the U.S. may well have been a consequence of its educational system, which provided a public alternative to a private education that was outside the reach of many families.

The importance of free, public education provides a less satisfactory explanation for the trend in mobility over time within the U.S., though: while enrollment rates, graduation rates, and 
spending have increased dramatically since the nineteenth century (Goldin, 1999, pp. 52-68),

intergenerational occupational mobility has nonetheless fallen. Though the educational requirements

to advance in occupational status (or to avoid a decline in occupational status) may have risen more

rapidly than the aggregate statistics on the provision of education, there is no evidence with which to

confront this conjecture. ${ }^{25}$

A potentially more promising avenue for explaining both the U.S. advantage in mobility

compared to Britain within the nineteenth century and the decline in relative U.S. mobility since the

nineteenth century is to consider characteristics of the U.S. economy that correspond to both of

these contrasts. The most obvious candidate is residential mobility. ${ }^{26}$ Both Schultz (1961) and Becker

(1964) suggested viewing migration as an investment. In the Becker and Tomes (1980) framework,

changes in location undertaken by the family can produce occupational mobility just as investment

by the family in the child's human capital. After childhood, the individual himself may undertake

such investment to compensate for under-investment by a credit-constrained family or to take

${ }^{25}$ Becker and Tomes (1986, p. S31) suggest with some justification that capital constraints construed more generally fell from the nineteenth century to the twentieth in the U.S. But this, too, runs counter to the trend of decreasing mobility from the nineteenth century to the twentieth. The model's prediction that larger family size will be a ssociated with lower investm ent per child and lower mobility (if fertility is exogenous) is another force working a gainst the finding of relatively greater m obility in the nineteenth cent ury U.S. than in the twentieth: the total fertility rate in the U.S. fell from 5.42 in 1850 to 2.98 in 1950.

26 The unusually high rates of residential mobility in the nineteenth century U.S. were remarked upon by de Tocqueville (1835) who observed that in the U.S., "millions of men are marching at once toward the same horizon; their language, their religion, their manners differ; their object is the same. Fortune has been promised to them somewhere in the west, and to the west they go to find it." These patterns were observed by him as well in places only recently settled: "I have spoken of the emigration from the older states but how shall I describe that which takes place from the more recent ones? Fifty years have scarcely elapsed since Ohio was founded; the greater part of its inhabitants were not born within its confines; its capital has been built only thirty years, and its territory is still covered by an immense extent of uncultivated fields; yet already the population of Ohio is proceeding westward, and most of the settlers who descend to the fertile prairies of Illinois are citizens of O hio. The se men left their first country to improve their con dition; th ey quit their second to ameliorate it still more; fortun e awaits them ev erywhere, but not happiness." 
advantage of investment opportunities that were unavailable to the family because they did not yet exist or were overlooked by them.

In the British 1851-81 sample, 27 percent of sons crossed a county boundary over these three decades, while in the U.S. 1850-80 sample, 62 percent did so. ${ }^{27}$ In fact, in the U.S., men changed states over thirty years as often as men in Britain changed counties. Though we lack comparable data on mobility over a span of thirty years for the twentieth century U.S., the National Longitudinal Survey (NLS) cohorts of Older Men and Young Men provide a comparison over ten years, the shortest span we can observe in the nineteenth century linked files. Between 1870 and 1880, 55 percent of young (20-29 years) white, native-born males changed county and 30 percent changed state; between 1971 and 1981, only 42 percent of otherwise identical males changed county, while only 22 percent changed state. Among older men (45-59 years) the declines in both intercounty mobility (from 35 percent 1870-80 to 16 percent 1966-76) and inter-state mobility (from 22 percent $1870-80$ to 8 percent 1966-76) were even more dramatic.

Though mid-nineteenth century Britain was a considerably more compact economy with an extensive transportation network, residential mobility was greater in the mid-nineteenth century U.S. Though the U.S. experienced substantial improvements in transportation and flows of information from the third quarter of the nineteenth century to the third quarter of the twentieth, residential mobility rates actually fell. This suggests that the retum to mobility in the $1850-80$ period must have been substantial - greater than in late nineteenth century Britain and greater than in the modern U.S. It would be a mistake to attribute this high return directly to the presence of an open frontier in the nineteenth century U.S., however, for two reasons: (1) both residential and occupational mobility

\footnotetext{
${ }^{27}$ British counties were roughly the same size on average as U.S. counties.
} 
remained high through 1910, fully two decades after the closing of the frontier; and (2) the frontier was never the destination for more than a small fraction of U.S. internal migrants after 1850.

Residential mobility may nonetheless have provided an alternative to direct investment in human capital. Kim (1998) has shown that regional specialization in the U.S. increased through 1880, fell slightly through 1910, and then fell dramatically throughout the rest of the twentieth century. This raises the possibility that throughout the second half of the nineteenth century, differences in the economic activities undertaken in different places left open another route to advancement: migration to places that were growing more rapidly than others. Some of these places of unusual opportunity were cities that sprang up initially to provide services demanded as the frontier expanded. For example, Chicago's population grew ten-fold in just the twenty years after 1850, then nearly tripled over the next two decades, providing a site of substantial opportunity. (Galenson, 1991) Though U.S. labor markets were well-integrated at the regional level by the middle of the nineteenth century, at least within the North (Margo, 2000; Rosenbloom, 1996), differences across smaller units of geography may have continued to present opportunities for "locational arbitrage" that provided a route to occupational change through the start of the twentieth century.

\section{Conclusion}

Though the U.S. exhibited no more intergenerational occupational mobility in the late twentieth century than similarly developed countries, a widely-shared belief that the U.S. is a place of unusually easy mobility has consistently guided public policy and shaped debate regarding the appropriate functions of the government in promoting social welfare from the 1930 s to the present. Using new longitudinal data for the nineteenth century, we have identified an era when the U.S. mobility experience was indeed exceptional: even after controlling for differences in their occupational structures, the U.S. had substantially more occupational mobility across generations 
than either Britain in the three decades after 1850 or the modern U.S. Though it remains to be seen exactly why nineteenth century U.S. mobility exceeded that in both nineteenth century Britain and the twentieth century U.S., and when the transition to a lower mobility regime in the U.S. took place, high U.S. intergenerational occupational mobility corresponded to high rates of residential mobility. A fall in U.S. residential mobility after 1910 as economic activity across locations became more homogenous may have reduced the ability of families and individuals to "invest through migration" and foster occupational mobility across generations. 


\section{Appendix}

The population censuses of Britain and the U.S. are generally regarded to be the best sources of individual-level, nationally representative data from the nineteenth century for those countries. However, the cross-sectional censuses do not provide the continuity over time needed to study issues of mobility at the level of the individual. Two new sources have made it possible to create the necessary continuity from the British and U.S. historical census records. The Genealogical Society of Utah in conjunction with the Federation of Family History Societies has computerized the individual-level records from the enumerators' books of the 1881 Census of the Population of England, Wales, and Scotland and from the 1880 U.S. Federal Population Census. These data make it possible to search for specific individuals in the 1881 British or 1880 U.S. census. To construct the data for this study, we searched for individuals from two other censuses: the 1851 British and the 1850 U.S. census.

For Britain, we attempted to match all the English and Welsh born males age 25 and below from the computerized two percent sample of the 1851 census compiled principally by Anderson, Collins, and Stott. For the U.S. we attempted to match white males age 25 and below from the 1850 Federal Census one percent public use sample. ${ }^{28}$ We employed a common matching technique for the British and U.S. data. Both countries' censuses provide information that either remains consistent between enumerations (name and birthplace) or changes predictably (age) that can be used to identify a given individual in more than one census. The British census has more specific

28 The 1851 data for Britain are from a 2\% Public Use Sample available as Study No. 1316 from the U.K. Data Archive at the University of Essex (http://www.dataarchive.ac.uk). It is a stratified two percent systematic cluster sample from the enumerators' books. For a full description see Anderson (1987). The complete 1881 census for Britain was obtained as Study No.3643 from the U.K. Data Archive. The 1880 U.S. file was obtained from the North American Population Project (http://www.nappdata.org) and the 1850 U.S. 1\% Public Use Sample was obtained from the Integrated Public Use Microdata Series available from the Minnesota Population Center (http://www.ipums.org). 
information than the U.S. census on each individual's birthplace (parish in Britain, state in the U.S.). In the 1880 U.S. census, respondents were asked to give the place of birth of their parents as well (state for those whose parents were born in the U.S. and country for those whose parents were born abroad). This question was missing entirely from the nineteenth century British census.

For Britain, in order to be considered a true match for an individual from 1851, an individual from 1881 had to have either the same name or a close phonetic variation thereof (for example, Aitken and Aitkin were considered to be equivalent), a year of birth different by no more than five years, and the same county and parish of birth. For the U.S., the individual must provide the same state of birth for himself (and his parents if they were present in 1850) in 1850 and 1880, and the year of birth could differ by no more than three years. The variation in birth year was allowed in order to account for age misreporting, a fairly common phenomenon in nineteenth century societies which lacked the systematic record keeping and where individuals often had only an approximate idea of their age. ${ }^{29}$ None of the matching information could be missing from an individual's record. Also, only unique matches were considered: if an individual from the 1850/51 sample had more than one match in the $1880 / 81$ census, then that individual was dropped. ${ }^{30}$

Applying this matching process to 69,785 English and Welsh males age 25 and under from the 1851 two percent sample yielded 14,191 men observed in Britain both in 1851 and 1881, a success rate of $20 \%$. From a pool of 43,438 U.S. white males age 25 and under in 1850, 9,497 were found in the 1880 U.S. census, a 22 percent success rate. For each country, the data come from two nationally representative sources, so as long as the matching process does not skew the sample, the

29 The smaller margin of age reporting error for the U.S. matching process is in response to the less specific birthplace information. For a discussion of age enumeration in the Victorian census, see Higgs (1986).

30 The same proced ure created the 1860-80, 1880-1900, and 1870-80 linked U.S. samples. 
set of matched individuals should also be representative of the two national populations that survived 1850-80 and 1851-81. In order to assess the representativeness of the linked samples, we compared their characteristics to those in the public use samples for the initial year (1850 or 1851) and terminal year (1880 or 1881). Tables A-1 and A-2 present marginal effects from probit regressions in which the dependent variable is 1 for observations from the linked sample and 0 for observations from the public use sample. ${ }^{31}$

In general, the matched samples represent the overall population quite well. Though several of characteristics exert a statistically significant influence on the probability of linkage, compared to the predicted probability the magnitude is small in each case. ${ }^{32}$ In order to reduce the impact of these already small differences between the linked samples and the general population, we constructed weights to produce linked samples that would duplicate the marginal frequencies of the characteristics in the general population. (Deming and Stephan, 1940) Two sets of weights were generated, one for the initial year and one for the terminal year. In Columns (2) and (4) of Tables A1 and A-2, the weights are imposed on the linked individuals, leaving them statistically indistinguishable from the general population. Though we have used the unweighted data throughout this paper, the results are insen sitive to the imposition of these weights.

\footnotetext{
${ }^{31}$ Each linked individual thus enters the regression twice: once in the linked sample and once in the public use sample. This is done to facilitate comparison with the regressions in Columns (2) and (4) of each table in which weights are imposed to make the linked individuals nationally-representative (rather than merely indistinguishable from the unlinked). For the British, 8,655 individuals in the public use sample for 1851 were missing one or more of the characteristics used in the probit analysis and were dropped from the regressions in Columns (1) and (2) of Table A-2. For the comparisons with 1880 and 1881, 25 percent random samples of the complete files for those years were used rather than the complete files.

32 The large coefficients on the migration history variables in Column (3) of Table A-2 result from the inability to identify the year of arrival in the U.S. for immigrants present in the U.S. in 1880 (the excluded category in the regression).
} 


\begin{tabular}{|c|c|c|c|c|}
\hline Variable & $\begin{array}{c}\text { 1850, No W eights } \\
\partial \mathrm{P} / \partial \mathrm{X}\end{array}$ & $\begin{array}{c}\text { 1850, Weights } \\
\partial \mathrm{P} / \partial \mathrm{x}\end{array}$ & $\begin{array}{c}1880, \text { No W eights } \\
(\partial \mathrm{P} / \partial \mathrm{x}) \times 100\end{array}$ & $\begin{array}{r}\text { 1880, Weights } \\
(\partial \mathrm{P} / \partial \mathrm{X}) \mathrm{x} 100 \\
\end{array}$ \\
\hline Age $15-25$ in 1850 & $\begin{array}{l}0.0017 \\
(0.41)\end{array}$ & $\begin{array}{l}0.0013 \\
(0.31)\end{array}$ & $\begin{array}{c}0.0314 \\
(14.38)^{* * *}\end{array}$ & $\begin{array}{l}0.0000 \\
(0.01)\end{array}$ \\
\hline \multicolumn{5}{|l|}{ Residence: } \\
\hline Midwest & $\begin{array}{l}-0.0478 \\
(11.26)^{* * *}\end{array}$ & $\begin{array}{l}-0.0008 \\
(0.19)\end{array}$ & $\begin{array}{l}-0.0216 \\
(8.40)^{* * *}\end{array}$ & $\begin{array}{l}0.0001 \\
(0.02)\end{array}$ \\
\hline South $^{a}$ & $\begin{array}{c}-0.0519 \\
(12.13)^{* * *}\end{array}$ & $\begin{array}{l}-0.0011 \\
(0.25)\end{array}$ & $\begin{array}{l}-0.0235 \\
(9.17)^{* * *}\end{array}$ & $\begin{array}{l}0.0002 \\
(0.04)\end{array}$ \\
\hline West & & & $\begin{array}{l}-0.0398 \\
(7.83)^{* * *}\end{array}$ & $\begin{array}{l}0.0003 \\
(0.02)\end{array}$ \\
\hline Population $>2,500$ & $\begin{array}{l}-0.0013 \\
(0.25)\end{array}$ & $\begin{array}{l}-0.0028 \\
(0.52)\end{array}$ & & \\
\hline \multicolumn{5}{|l|}{ Migration History: } \\
\hline Interstate Mover & $\begin{array}{l}-0.0124 \\
(1.34)\end{array}$ & $\begin{array}{l}-0.0001 \\
(0.01)\end{array}$ & $\begin{array}{c}0.3214 \\
(43.35)^{* * *}\end{array}$ & $\begin{array}{l}-0.0001 \\
(0.02)\end{array}$ \\
\hline Birthstate $=$ Residence & $\begin{array}{l}0.0090 \\
(1.10)\end{array}$ & $\begin{array}{l}0.0001 \\
(0.01)\end{array}$ & $\begin{array}{c}0.3123 \\
(50.16)^{* * *}\end{array}$ & $\begin{array}{l}-0.0002 \\
(0.03)\end{array}$ \\
\hline Family Size & $\begin{array}{l}-0.0003 \\
(0.44)\end{array}$ & $\begin{array}{l}-0.0003 \\
(0.35)\end{array}$ & $\begin{array}{l}-0.0004 \\
(1.22)\end{array}$ & $\begin{array}{l}-0.0004 \\
(0.50)\end{array}$ \\
\hline \multicolumn{5}{|l|}{ Occupation ${ }^{\mathrm{b}}$ : } \\
\hline Farmer & $\begin{array}{c}0.0138 \\
(2.07)^{* *}\end{array}$ & $\begin{array}{l}-0.0015 \\
(0.22)\end{array}$ & $\begin{array}{l}0.0126 \\
(4.16)^{* * *}\end{array}$ & $\begin{array}{l}-0.0003 \\
(0.04)\end{array}$ \\
\hline Skilled & $\begin{array}{l}0.0003 \\
(0.05)\end{array}$ & $\begin{array}{l}-0.0011 \\
(0.14)\end{array}$ & $\begin{array}{l}-0.0014 \\
(0.38)\end{array}$ & $\begin{array}{l}-0.0001 \\
(0.01)\end{array}$ \\
\hline Semi-Skilled & $\begin{array}{l}0.0086 \\
(0.93)\end{array}$ & $\begin{array}{l}-0.0008 \\
(0.08)\end{array}$ & $\begin{array}{l}-0.0012 \\
(0.28)\end{array}$ & $\begin{array}{l}-0.0000 \\
(0.00)\end{array}$ \\
\hline Laborer & $\begin{array}{l}0.0128 \\
(1.52)\end{array}$ & $\begin{array}{l}-0.0019 \\
(0.22)\end{array}$ & $\begin{array}{l}-0.0102 \\
(2.85)^{* * *}\end{array}$ & $\begin{array}{l}0.0001 \\
(0.01)\end{array}$ \\
\hline Other & $\begin{array}{l}-0.0106 \\
(0.88)\end{array}$ & $\begin{array}{l}-0.0011 \\
(0.09)\end{array}$ & $\begin{array}{l}-0.0059 \\
(0.98)\end{array}$ & $\begin{array}{l}-0.0001 \\
(0.01)\end{array}$ \\
\hline \multicolumn{5}{|l|}{ Household Real Estate: } \\
\hline $0<$ Real Estate $<\$ 1,500$ & $\begin{array}{c}0.0104 \\
(2.37)^{* *}\end{array}$ & $\begin{array}{l}0.0024 \\
(0.54)\end{array}$ & & \\
\hline Real Estate $\geq \$ 1,500$ & $\begin{array}{c}0.0255 \\
(5.62)^{* * *}\end{array}$ & $\begin{array}{l}-0.0025 \\
(0.56)\end{array}$ & & \\
\hline Father Literate & $\begin{array}{l}-0.0067 \\
(1.09)\end{array}$ & $\begin{array}{l}-0.0058 \\
(0.93)\end{array}$ & & \\
\hline Atten ded S chool & $\begin{array}{l}0.0065 \\
(1.82)^{*}\end{array}$ & $\begin{array}{l}0.0006 \\
(0.17)\end{array}$ & & \\
\hline Household Head & & & $\begin{array}{l}-0.0014 \\
(0.35)\end{array}$ & $\begin{array}{l}0.0024 \\
(0.26)\end{array}$ \\
\hline Married & & & $\begin{array}{l}0.0094 \\
(2.65)^{* * *}\end{array}$ & $\begin{array}{l}-0.0022 \\
(0.25)\end{array}$ \\
\hline Observations & 52,935 & 52,935 & $1,766,147$ & $1,766,147$ \\
\hline Pseudo- $\mathrm{R}^{2}$ & 0.0071 & 0.0001 & 0.0356 & 0.0000 \\
\hline Predicted Probability & 0.1794 & 0.1794 & 0.0014 & 0.0014 \\
\hline $\begin{array}{l}\text { Absolu te value of } \mathrm{z} \text { statistics in } \\
\text { 1850," "Northeast,", "Populat } \\
\text { Illiterate," "Not Attending Sch } \\
\text { a Include s "West" in } 1850 .{ }^{b} \text { Fa }\end{array}$ & $\begin{array}{l}\text { enth eses. * significant } \\
\leq 2,500 \text { ", "Foreign-Bo } \\
\text { " "Non-Head," and " } \\
\text { 's occupation in } 1850\end{array}$ & $\begin{array}{l}\text { at * } 10 \% ; * * 5 \% \\
\text { orn," "White Col } \\
\text { Unmarried." } 188 \\
\text {, Son's occupatio }\end{array}$ & $\begin{array}{l}0 ; * * * 1 \% . \text { Omitted ca } \\
1 \text { lar," "Household Rea } \\
80 \text { uses a } 25 \% \text { sample } \\
\text { on in } 1880 .\end{array}$ & $\begin{array}{l}\text { categ ories: "A ge } 0 \\
\text { eal Estate }=0, \text { " "F } \\
\text { le of the unlinked }\end{array}$ \\
\hline
\end{tabular}

Table A-1. Probit Marginal Effects on Linkage (1=linked sample, 0=Public Use Sample), U.S. 


\begin{tabular}{|c|c|c|c|c|}
\hline Variable & $\begin{array}{c}\text { 1851, No W eights } \\
\partial \mathrm{P} / \partial \mathrm{X}\end{array}$ & $\begin{array}{c}\text { 1851, Weights } \\
\partial \mathrm{P} / \partial \mathrm{X}\end{array}$ & $\begin{array}{c}\text { 1881, No W eights } \\
\partial \mathrm{P} / \partial \mathrm{X}\end{array}$ & $\begin{array}{c}\text { 1881, Weights } \\
\partial \mathrm{P} / \partial \mathrm{X}\end{array}$ \\
\hline \multirow[t]{2}{*}{ Age $15-25$ in 1851} & 0.0069 & 0.0015 & -0.0015 & 0.0000 \\
\hline & $(1.48)$ & $(0.30)$ & $(21.32)^{* * *}$ & $(0.44)$ \\
\hline \multicolumn{5}{|l|}{ Residence: } \\
\hline \multirow[t]{2}{*}{ London } & 0.0335 & 0.0067 & 0.0011 & -0.0002 \\
\hline & $(4.46) * * *$ & $(0.87)$ & $(6.41)^{* * *}$ & $(1.12)$ \\
\hline \multirow[t]{2}{*}{ Midlands-East } & 0.0354 & 0.0078 & 0.0012 & -0.0002 \\
\hline & $(4.97)^{* * *}$ & $(1.06)$ & $(7.21)^{* * *}$ & $(0.94)$ \\
\hline \multirow[t]{2}{*}{ North } & 0.0405 & 0.0091 & 0.0004 & -0.0002 \\
\hline & $(5.66) * * *$ & $(1.23)$ & $(2.85)^{* * *}$ & $(1.15)$ \\
\hline \multirow[t]{2}{*}{ South } & 0.0305 & 0.0056 & 0.0022 & -0.0002 \\
\hline & $(4.17)^{* * *}$ & $(0.75)$ & $(11.58)^{* * *}$ & $(0.90)$ \\
\hline \multicolumn{5}{|l|}{ Migration History: } \\
\hline \multirow[t]{2}{*}{ Birth County $=$ Residence } & 0.0698 & 0.0014 & 0.0007 & 0.0000 \\
\hline & $(13.64)^{* * *}$ & $(0.22)$ & $(9.66) * * *$ & $(0.52)$ \\
\hline \multicolumn{5}{|l|}{ Occupation ${ }^{\mathrm{a}}$ : } \\
\hline \multirow[t]{2}{*}{ Farmer } & 0.0148 & 0.0030 & 0.0014 & 0.0000 \\
\hline & $(3.90) * * *$ & $(0.78)$ & $(8.65)^{* * *}$ & $(0.01)$ \\
\hline \multirow[t]{2}{*}{ Craftsman } & 0.0332 & 0.0065 & 0.0005 & -0.0001 \\
\hline & $(5.52)^{* * *}$ & $(1.09)$ & $(6.00)^{* * *}$ & $(1.03)$ \\
\hline \multirow[t]{2}{*}{ Laborer } & 0.0131 & 0.0023 & 0.0000 & -0.0001 \\
\hline & $(3.69)^{* * *}$ & $(0.62)$ & $(0.44)$ & $(0.81)$ \\
\hline \multirow[t]{2}{*}{ Attended School } & 0.0167 & 0.0026 & & \\
\hline & $(4.81)^{* * *}$ & $(0.73)$ & & \\
\hline \multirow[t]{2}{*}{ Employed Outside Home } & 0.0096 & 0.0013 & & \\
\hline & $(2.09)^{* *}$ & $(0.28)$ & & \\
\hline \multirow[t]{2}{*}{ Married } & & & 0.0000 & 0.0001 \\
\hline & & & $(0.42)$ & $(0.42)$ \\
\hline \multirow[t]{2}{*}{ Head } & & & 0.0014 & 0.0000 \\
\hline & & & $(13.01)^{* * *}$ & $(0.23)$ \\
\hline Observations & 75,321 & 75,321 & 934,852 & 934,852 \\
\hline Pseudo- $\mathrm{R}^{2}$ & 0.0043 & 0.0001 & 0.0065 & 0.0000 \\
\hline Predicted Probability & 0.1830 & 0.1886 & 0.0038 & 0.0041 \\
\hline \multicolumn{5}{|c|}{$\begin{array}{l}\text { Absolu te value of } z \text { statistics in parenth eses. * significant at } 10 \% ; * * 5 \% ; * * * 1 \% \text {. O mitted categor ies: "Age } 0-14 \text { in } \\
1851, \text { " "Wales," "Oth er." } 1881 \text { uses a } 25 \% \text { sam ple of the unlinked. }{ }^{a} \text { Father's occupation in } 1851 \text {, Son's occup ation in } \\
1881 .\end{array}$} \\
\hline
\end{tabular}

Table A-2. Probit Marginal Effects on Linkage (1=linked sample, 0=Public Use Sample), Britain.

A final concern is whether the linkage process has resulted in too many "false po sitives" (individuals who are not in fact the same person in both the initial and terminal years). For the comparison between the U.S. and Britain in the nineteenth century, this is a difficulty if the sample for one country has more false positives than the sample for the other. For example, more false positives in the U.S. than in Britain will generate more "noise" in comparing the occupations of 
fathers and sons, and lead to a spurious finding of greater occupational mobility in the U.S. than in Britain. For the comparison over time within the U.S., it is also a problem, because the data for the twentieth century were constructed in a way that prevented such incorrect matches (the respondent in the OCG was asked himself to state the occupation of his father when the respondent was 16 years of age). Greater "noise" in the nineteenth century U.S. data would also produce a spurious finding of greater mobility in the nineteenth century U.S. than in the twentieth.

The comparison between mobility in Britain 1851-81 and in the U.S. 1850-80 was performed again, but this time with the samples restricted to those whose surnames matched exactly and whose age was off by no more than one year. The results were quite similar to those shown in the second panel of Table 2:

$\mathrm{P}=$ Britain 1851-81, $\mathrm{Q}=\mathrm{U} . \mathrm{S} .1850-80$

$\mathrm{d}(\mathrm{P}, \mathrm{I})=24.50($ prob $<0.0001)$

$\mathrm{d}(\mathrm{Q}, \mathrm{I})=14.22($ prob $<0.0001)$

$\mathrm{d}(\mathrm{P}, \mathrm{Q})=15.22($ prob $<0.0001)$

Though mobility in the U.S. with the more restricted sample is slightly farther from what we would observe if the occupations of fathers and sons were independent, the difference between mobility in the U.S. and in Britain is actually slightly greater. When the 1880-1900 U.S. sample is restricted to those whose surname matched exactly and whose age was off by no more than a year, the nineteenth century U.S. remained substantially more mobile than the twentieth century though the magnitude of the difference is reduced. We again can reject the null hypothesis that the association between the occupations of fathers and sons was identical in these two eras:

P=U.S. 1880-1900, Q=U.S. 1953-73

$\mathrm{d}(\mathrm{P}, \mathrm{I})=15.90($ prob $<0.0001)$

$\mathrm{d}(\mathrm{Q}, \mathrm{I})=20.76($ prob $<0.0001)$

$\mathrm{d}(\mathrm{P}, \mathrm{Q})=6.94($ prob $<0.005)$. 


\section{References}

Anderson, Michael (1987). "National Sample from the 1851 Census of Great Britain: Introductory User Guide." University of Edinburgh, Dept. of Economic and Social History.

Alberto Alesina, Rafael Di Tella, Robert MacCulloch (2001). "Inequality and Happiness: Are Europeans and Americans Different?” NBER Working Paper No. w8198.

Altham, P.M. (1970). "The Measurement of Association of Rows and Columns for an $r \times s$ Contingency Table." Journal of the Royal Statistical Society, Series B, 32: 63-73.

Altham, P.M., and J.P. Ferrie (2005). “Contingency Table Com parisons.” W orking Paper, Northwe stern University Department of Economics.

Becker, Gary (1964). Human Capital (New York: National Bureau of Eco nomic Research).

Becker, Gary, and Tomes, Nigel (1986). "Human Capital and the Rise and Fall of Families." Journal of Labor Economics, 4, S1-S39.

Björklu nd, Anders, and Marku s Jäntti (1999). "In tergenerational Mobility of S ocio-Economic Statu s in Comparative Perspective." Working paper (Septem ber).

Deming, W.E., amd F.F. Step han (1940). “On a Least Square s Adju stment of a Sam pled Frequency Table When the Expected Marginal Totals Are Known." Annals of Mathematical Statistics, 11: 427-444.

Easterlin, Richard A. (1981). "W hy Isn't the Whole W orld Developed?” Journal of Economic History, 41 (Mar.): 1-19.

Erikson, Robert, and John H. Goldthorpe (1992). The Constant Flux : A Study of Class Mobility in Industrial Societies (Oxford: Clarendon Press).

Ferrie, Jose ph P. (forthcoming). "The End of Am erican Exceptionalism? Occu pational and Geograph ic Mobility in the U.S. Since 1850." Journal of Economic Perspectives (Sept.).

Galen son, David W. (1991). "Economic Opportunity on the Urb an Fron tier: Nativity, Work, and W ealth in Early Chicago.” Journal of Economic History, 51: 581-603.

Goldin, Claudia D. (1999). "A Brief History of Education in the United States.” NBER Historical Working Paper No. 119 (A ugust).

Grawe, Nathan D., and Casey B. Mulligan,-Casey-B (2002). "Economic Interpretations of Intergenerational Correlations." Journal of Economic Perspectives, 16 (Summer ): 45-58.

Grusky, David B. (1987). American Occupational Mobility in the 19th and 20th Centuries. Ph.D. dissertation, University of Wisconsin, Madison.

Grusky; David B., and Robert M. Hauser (1984). "Comparative Social Mobility Revisited: Models of Convergence and Divergence in 16 Countries." American Sociological Review, 49 (Feb.): 19-38. 
Guest, Avery M., Nancy S. Landale, and James L. McCann (1989). "Intergenerational Occupation al Mobility in the Late Nineteenth Century United States.” Social Forces, 68: 351-378.

Han, Song, and Casey B. Mulligan (2001). "Human Capital, Heterogeneity, and Estimated Degrees of Intergenerational Mobility.” Economic Journal, 111 (April): 207-243.

Hauser, Robert M. (1980). "Some Exploratory Methods for Modeling Mobility Tables and O ther CrossClassified Data." Sociological Methodology, 11: 413-458.

Higgs, Edward. (1986). A Clearer Sense of the Census (London: HMSO).

Kerkh off, Alan C., Richard T. Campbell, and Idee Win field-Laird (1985). "Social Mobility in Great Britain and the United States." American Journal of Sociology, 91 (September): 281-308.

Kim, Sukkoo (1998). “Economic Integration and Convergence: U.S. Regions, 1840-1987.” Journal of E conomic History, 659-683.

Margo, Robert A. (2000). Wages and Labor Markets in the United States, 1820-1860 (Chicago : University of Chicago Press).

Marx, Karl (1863-83). Capital, v.3.

Marx, Karl (1852). “The Eighteenth Brumaire of Louis Napolean.” Selected Works.

Marx, Karl (1865). "Value, Prices, and Profits." Selected Works.

Mazu mder, B hashkar (2001). "Earnings Mobility in the U.S.: A New Look at Intergenerational Inequality." Federal Reserve Bank of Chicago Working Paper No. W P 2001-18 (D ecember).

McMurrer, Daniel P. , Mark Condon, and Isabel V. Sawhill (1997). "Intergenerational Mobility in the United States." Urban Institute Research Paper No. 406796 (M ay).

Miles, Andrew (1999). Social Mobility in Nineteenth-and Early Twentieth-century England (Houndmills, Basingstoke, Ham pshire : Macmillan).

Miles, Andrew. (1993). "How Open Was Nineteenth-Century British Society? Social Mobility and Equality of Opportunity, 1839-1914.” In A ndrew Miles and David Vincent (eds.), Building European Society: Occupational Change and Social Mobility in Europe, 1840-1940 (Manchester: Man chester University Press).

Mitch, David. (1993). “Inequalities Which Every One May Remove’: Occupational Recruitment, Endogamy, and the Homogeneity of Social Origins in Victorian England." In Andrew Miles and David Vincent (eds.), Building European Society: Occupational Change and Social Mobility in Europe, 1840-1940 (Manch ester: Manchester Unive rsity Press).

Mosteller, Frederick (1968). "A ssociation and Estimation in Con tingency Table s." Journal of the American Statistical Association, 63: 1-28.

Piketty, Thomas (1995). "Social Mobility and Redistributive Politics." The Quarterly Journal of Economics, Vol. 110, No. 3. (Aug., 1995), pp. 551-584. 
Rosenbloom, Joshua (1996). "Was There a National Labor Market at the End of the Nineteenth Century? New Evidence on Earnings in Manufacturing." Journal of Economic History, 56: 626-656.

Schultz, Theodore W. (1961). "Investment in Human Capital." American Economic Review, 51: 1-17.

Solon, Gary (1999). "Intergenerational Mobility in the Labor Market." In Orley A shenfelter and D avid Card (eds.), Handbook of Labor Economics, Vol 3 (New York: Elsevier).

Solon, Gary (2002). "Cross-Country Differences in Intergenerational Earnings Mobility." Journal of Economic Perspectives, 16 (Summer ): 59-66.

Sombart, Werner (1906 [1976]). Why Is There No Socialism in America, translated by Patricia Hocking and C.T. Husbands (N ew York: M.E. Sharpe).

Thernstrom, Stephan (1973). The Other Bostonians: Poverty and Progress in the American Metropolis, 1880-1970 (Cambridge: Harvard University Press).

de Tocqueville, Alexis (1835). Democracy in America.

Treiman, Donald J., and Harry B. G. Ganzeboom (2000). "The Fourth Generation of Comparative Stratification Rese arch." In S tella R. Quah and Arnaud Sales (eds.), The International Handbook of Sociology (Lond on: Sage).

Turner, Frederick Jackson (1921). The Frontier in American History (New York: Henry Holt and Company).

U.S. Census Office (1891). Distribution of population according to density: 1890, Extra Census Bulletin No. 2, April 20, 1891.

Vincent, David (1989). Literacy and Popular Culture: England 1750-1914 (Cambridge: Cambridge Unive rsity Press).

Wong, Raym ond Sin-Kwok (1990). "Un derstan ding C ross-National Va riation in O ccupational Mobility." American Sociological Review, 55 (Aug.): 560-573.

Yamaguchi, Kazu o (1987). "Models for Compa ring Mobility Tables: Tow ard Parsimony and Substance." American Sociological Review, 52 (Aug.): 482-494. 